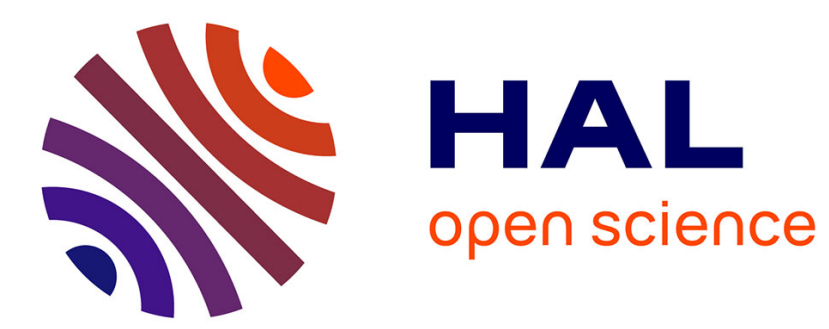

\title{
Trade Policy and Market Power: Firm-level Evidence
}

Alan Asprilla, Nicolas Berman, Olivier Cadot, Melise Jaud

\section{To cite this version:}

Alan Asprilla, Nicolas Berman, Olivier Cadot, Melise Jaud. Trade Policy and Market Power: Firmlevel Evidence. 2018. halshs-01945660

\section{HAL Id: halshs-01945660 \\ https://shs.hal.science/halshs-01945660}

Preprint submitted on 5 Dec 2018

HAL is a multi-disciplinary open access archive for the deposit and dissemination of scientific research documents, whether they are published or not. The documents may come from teaching and research institutions in France or abroad, or from public or private research centers.
L'archive ouverte pluridisciplinaire HAL, est destinée au dépôt et à la diffusion de documents scientifiques de niveau recherche, publiés ou non, émanant des établissements d'enseignement et de recherche français ou étrangers, des laboratoires publics ou privés. 


\section{amse}

école d'économie d'aix-marseille

aix-marseille school of economics

\section{Working Papers / Documents de travail}

Trade Policy and Market Power: Firm-level Evidence

Alan Asprilla

Nicolas Berman

Olivier Cadot

Melise Jaud 


\title{
Trade Policy and Market Power: Firm-level Evidence *
}

\author{
Alan Asprilla ${ }^{\dagger} \quad$ Nicolas Berman $^{\ddagger} \quad$ Olivier CADot $^{\S} \quad$ Melise JAud $^{\llbracket}$
}

December 4, 2018

\begin{abstract}
This paper identifies the effect of trade policy on market power through new data and a new identification strategy. We use a large dataset containing export values and quantities by product and destination for all exporting firms in 12 developing and emerging countries over several years, merged with destination-product specific information on tariffs and non-tariff barriers. We identify market power by observing how exporting firms price discriminate across markets in reaction to variations in bilateral exchange rates. Pricing-to-market is prevalent in all regions of our sample, even among small firms, although it is increasing in firm size, in accordance with theory. More importantly, we find that the effect of non-tariff measures is not isomorphic to that of tariffs: the pricing-to-market behavior we observe suggests that, while tariffs reduce the market power of foreign firms through classic rent-shifting effects, non-tariff measures alter market structure and reinforce the market power of non-exiting firms, domestic and foreign ones alike.
\end{abstract}

JEL classification: F12, F13, F14, D40, F31.

Keywords: Trade policy, non-tariff measures, tariffs, exchange rate, price discrimination.

\footnotetext{
*An earlier version of this paper was prepared as a background paper for the World Bank's "Champions Wanted" regional study and draws on prior research undertaken with support from the International Growth Center. We are grateful to George Alessandria, three referees, as well Paulo Bastos, Richard Newfarmer, Frederic Robert-Nicoud, and to seminar participants at CERDI, Nice Sophia-Antipolis, the Central Bank of Uganda, the World Bank, the ERF Annual Conference, the ETSG conference and the University of Lausanne for useful comments and suggestions. Special thanks to Caroline Freund for detailed advice. Jingjing Xia provided excellent research assistance. Support from France's Agence Nationale de la Recherche under "Investissement d'Avenir" grant ANR-10-LABX-14-01 and from Switzerland's NCCR under WP6, as well as from the governments of Norway, Sweden and the United Kingdom through the Multi-Donor Trust Fund for Trade and Development are gratefully acknowledged. Melise Jaud appreciates financial support from the Swiss National Science Foundation. Nicolas Berman thanks the A*Midex for financial support (grant ANR-11-IDEX-0001-02 funded by the French government "Investissement d'Avenir" program). This paper was partly written when Nicolas Berman was at the Graduate Institute of International and Development Studies, Geneva. The opinions expressed in this study are those of the authors and do not necessarily represent the views of the World Bank, its Board of Directors, or the governments that it represents. This paper features an online appendix containing additional results and available on the authors' webpages.

${ }^{\dagger}$ University of Lausanne. E-mail: alan.asprilla@unil.ch.

${ }^{\ddagger}$ Aix-Marseille Univ., CNRS, EHESS, Centrale Marseille, AMSE, France, and CEPR. E-mail: nicolas.berman@univ-amu.fr.

${ }^{\S}$ University of Lausanne, CEPR and FERDI. E-mail: olivier.cadot@unil.ch.

`University of Lausanne and World Bank. E-mail: melise.jaud@unil.ch.
} 


\section{Introduction}

While the argument that trade policy affects competition is an old one (see e.g. de Melo and Urata, 1986), there is to date little systematic evidence on how trade policy affects market power at the level of the firm and, in particular, how the effects of different trade-policy instruments play out. In a heterogeneous-firms setting, non-tariff measures (NTMs) - a widely used class of tradepolicy instrument including e.g. technical or sanitary regulations - affect market structure in ways that are not isomorphic to tariffs. Rather than merely shifting rents from foreign to domestic firms, they also change market structure by affecting firms differently depending on their size. For instance, a regulation may inadvertently create barriers to entry that generate a dominant position. Evidence of such effects of tariffs and NTMs is scarce, however, because assessing the market power of firms and how it relates to trade policy requires estimating indicators such as price-cost margins or market shares in well-identified markets. Both the identification of these measures and the definition of a market (and its structure) are problematic, which is why research has so far limited itself to specific sectors, countries and trade policy instruments.

This paper follows a different route and identifies market power and how it is affected by trade policy using insights from the pricing-to-market (PTM) literature. We rely on a growing literature that establishes, theoretically and empirically, that the extent of firm-level PTM relates to firm size, efficiency and, ultimately, market power. ${ }^{1}$ PTM implies that a firm faced with a cost shock will adjust its price differentially across destination markets, depending on the price elasticity of demand it perceives on each of them, which in turn depends on its market power. However, neither cost shocks nor market shares are observed directly at the firm level. ${ }^{2}$ Our identification strategy goes around this by relating firm-level export prices (on which we have data) to bilateral exchange rate shocks.

Consider a firm faced with a series of bilateral exchange rate shocks, one on each of its destination markets. If it passed through the entirety of each shock onto consumer prices, its producer price in the home currency would remain the same irrespective of destinations; there would be no PTM. However, with incomplete pass-through, a fraction of each shock is absorbed by the firm into its producer price; as a result, the uniqueness of the producer price breaks down, giving rise instead to a series of differentiated ones by destination. In other words, the firm prices to market. Like in the case of a symmetric cost shock, the reaction of a firm's producer price to an exchange rate shock tells us something about the elasticity of demand it perceives on its destination market-i.e., about its unobserved market power. Specifically, a firm with strong market power in a given destination (hence a low perceived price elasticity of demand) will absorb a large fraction of the bilateral exchange rate shock, and conversely. Because destination markets vary in terms of their trade policy, we can then infer the effect of trade policy on market structure by observing the pricing behaviour of firms exporting there, without directly needing to observe their market shares or any other measure of market power.

We start by discussing the impact of trade policy instruments on PTM in the destination country using a class of heterogenous firms models featuring variable and endogenous markups.

\footnotetext{
${ }^{1}$ See for example Krugman (1986), Feenstra et al. (1996), Atkeson and Burstein (2008), Berman et al. (2012), Auer and Schoenle (2016), or Amiti et al. (2014).

${ }^{2}$ Market shares are not even observed at the more aggregated product level, as domestic firm sales are typically not observed.
} 
We derive two main testable predictions, respectively related to non-tariff measures and to tariffs. Specifically, we show that NTMs applied in a non-discriminatory fashion - that is, in compliance with the WTO's "national treatment" clause, whereby imported and domestically-produced products must be treated alike - raise market power and PTM for incumbents if they induce the exit of smaller firms, e.g. through higher fixed costs. ${ }^{3}$ Import tariffs, on the other hand, decrease the sales of incumbents but also induce the exit of small firms, leading to an ambiguous impact on market power. However, given their discriminatory nature, tariffs are more likely to displace foreign firms in favor of domestic ones, implying that the intensive margin effect dominates and in net tariffs reduce the market shares of exporters and thus their incentive to engage in PTM. ${ }^{4}$

We then test these predictions using a large multi-country firm-level dataset obtained from customs administrations in twelve developing countries, ranging from low income to middle income. We combine the firm-level data with destination-product specific data on bilateral applied tariffs as well as non-tariff measures. The latter covers a wide range of measures ranging from sanitary and phytosanitary measures to technical barriers to trade. Pooling together firm-level data from several developing countries allows us to provide evidence on the extent of exchange rate pass-through for countries and regions that have received little attention so far, and to explore more systematically the impact of trade policy on competition and market power using a sample of countries facing different trade policy arrangements, in particular preferential tariffs. Importantly, the high dimensionality of the data enables us to account for unobserved heterogeneity and for a large set of confounding influences at the level of both the firm and the market using a powerful array of fixed effects. The fact that our unit of observation is a firm rather than a product or a country also implies that our estimates are unlikely to be driven by large firms, which is important given the skewness of the firm-size distribution.

Our results can be summarized as follow. First and consistent with the literature, PTM is observed in our sample, especially in the case of large firms. Faced with a $10 \%$ bilateral exchange rate depreciation on a given market, firms in our sample cut their home-currency price for export to that market by around $1.4 \%$ on average, implying incomplete although still high (86\%) exchange rate pass-through to export prices. ${ }^{5}$ Second and more importantly, trade policy significantly affects PTM, in a way that depends on the type of instrument. When exporters face non-tariff measures on their destination markets, they do more PTM. Tariffs have the opposite effect. Exporters faced with tariffs on their destination markets do significantly less PTM, as if tariffs were robbing them of some of their market power through rent-shifting effects. Considered jointly, the differential effects of tariffs and NTMs on PTM can be large. Consider an initial situation where a firm prices symmetrically on all markets. In the absence of tariffs and NTMs, a $10 \%$ bilateral exchange rate shock on market $i$ will create, ceteris paribus, a $0.7 \%$ wedge between the producer price of a given good shipped by that firm to $i$ and the same good shipped by the same firm to market $j$. In the presence of a $5 \%$ tariff on market $i$, the same shock will create only a $0.35 \%$ wedge. When tariffs reach $10-15 \%$ no significant adjustment is detected anymore in the home-currency export price, implying full pass-through. In markets with zero tariffs but

\footnotetext{
${ }^{3}$ We will leave aside the case of quantitative restrictions, as those have largely been phased out, and focus on regulations, either sanitary or technical, of which there is a plethora in high- and middle-income countries.

${ }^{4}$ In the online appendix, we also provide a detailed discussion of these predictions using a specific model from Atkeson and Burstein (2008).

${ }^{5}$ Interestingly, this rate remains quite stable across exporting countries and regions.
} 
with NTMs with large AVEs, we find that exchange rate pass-through drops dramatically from around $90 \%$ to $65 \%$. These results are robust to a battery of sensitivity checks. In particular, they still hold when controlling for all changes in firm-level costs which might be correlated with exchange rate movements through the inclusion of firm $\times$ product $\times$ year fixed effects.

What could account for this differential effect of tariffs and NTMs? A plausible conjecture is that if NTMs generate (fixed) compliance costs for all producers, they induce the exit of the smallest ones, raising the market share of all remaining ones, including foreign exporters. In that case, the market power of foreign exporters is enhanced by NTMs. We provide a number of complementary results which are in line with this interpretation. In particular, we perform exercises in the spirit of Fernandes et al. (2015) and Fontagné et al. (2015) and regress measures of the intensive and extensive margins of trade on NTMs and tariffs at the firm and product levels. We show that higher NTMs in a given market are associated with less exporters and more concentrated sales, and, if anything, have a slightly positive effect on import shares. Tariffs on the other hand are mostly correlated with measures of export performance at the intensive margin.

These results have important policy implications. Indeed, with tariffs on many manufactured products down to low levels, non-tariff measures have taken an increasing importance in regional trade negotiations, whether "mega-regionals" (e.g. TPP or TTIP) or existing ones such as ASEAN, which have tried to prevent them from replacing tariffs as trade barriers. Current policy approaches consist essentially in quantifying their trade effects through ad-valorem equivalents, feeding them into computable general equilibrium models, and hoping to cut them down through inter-governmental negotiations. However, little progress has been achieved so far. While political-economy factors may well have contributed to the lack of progress, this paper argues that trade-based approaches may also be going down the wrong alley. Our results suggest that NTMs should be viewed as a competition-policy issue as much as a trade one. They are not mere surrogates to tariffs, contrary to what a large part of the literature typically assumes, and they may affect market structure in terms of large vs. small firms more than home vs. foreign ${ }^{6}$ Considering them through this perspective would help shift the policy perspective away from doomed trade negotiations to more constructive approaches emphasizing cooperation between regulatory and antitrust agencies (within and between countries) in the design of regulations.

Our results also suggest that trade policy is an important element to consider when trying to understand the transmission of shocks across countries through prices. In the last section of the paper, we indeed show that our results also hold at the product- and country level, i.e. that tariffs and NTMs affect aggregate pass-through. By impacting overall competition, market structure and markups, trade policy is also likely to have important effects on aggregate welfare (Edmond et al., 2018).

Our work relates to various strands of the literature. Our paper is close to a number of papers that examine the role of trade policy and trade reforms on market power and pricing behaviour. For instance, looking at the U.S. steel industry and using plant-level census data, Blonigen et al. (2013) find that, as suggested by traditional theory, quota-based protection increases the market power of domestic producers while tariff-based protection does not. Kim (2000) provide similar

\footnotetext{
${ }^{6}$ See e.g. Feenstra (1984), Leamer (1990), Anderson and Neary (1994), Kee et al. (2009), Carrere and de Melo (2011).
} 
results based on Korean sector-level data. Antidumping protection, which takes the form of tariffs (or, sometimes, price agreements), has also received some attention, although results are ambiguous. ${ }^{7}$ Papers by De Loecker et al. (2016) and De Loecker et al. (2014) also provide evidence that the markups of domestic firms are affected by tariff reductions. These studies generally use measures of price-cost margins at the firm level to identify market-power effects.

The main problem faced by this literature is that estimating markups over marginal costs requires the use of detailed data on costs and/or strong identifying assumptions. ${ }^{8}$ Using market shares as a measure of market power is also problematic, both because one has to define what the appropriate "market" is and because, when studying exporters, the sales of domestic firms are typically not observed. Most of the papers cited above use very detailed firm-level data, allowing for a precise identification of the channels through which trade policy affect markups; but this comes at a cost: these studies are typically limited to a single country - often a single industry and focus exclusively on domestic producers. Using exchange rate variations to identify price discrimination and therefore market power across destinations has the advantage of requiring data on neither firm costs nor market shares. The idea that useful information on the extent of market power can be generated from price adjustments to exchange rate fluctuations is not new, as it was already present in early work such as Aw (1993), Goldberg and Knetter (1999) or Bernhofen and $\mathrm{Xu}$ (2000). ${ }^{9}$ Our study, which is close in spirit to those papers, links the literature on PTM with that on trade policy and competition.

We also contribute to the recent literature documenting the effect of tariffs and NTMs on exporters' performance. Fontagné et al. (2015) use French firm-level data and show that SPS concerns raised at the WTO raise firms' unit values and inhibit their entry. Interestingly, they show that these effects are not neutral on the distribution of firms, as smaller ones seem to react more strongly. Using a similar strategy, Fontagné and Orefice (2018) study TBT concerns instead and show that firms' exit probability increases in destinations with restrictive TBTs, an effect that is magnified in multi-destination firms who are able to divert their exports to TBT-free destinations. Fernandes et al. (2015) focus on the impact of pesticide standards on firms' exports of agricultural products and show that more restrictive standards lower the firms' probability to export as well as their export values and quantities. These papers help understand the mechanisms through which NTMs affect trade. However, they do not speak directly about their impact on market power, which cannot be directly measured in the absence of information on the entire set of firms, both foreign and domestic. In that sense, we view our paper as complementary to these works: we focus on a somewhat narrower question (we look at only one outcome), but we are able to identify cleanly the link between trade policy and market power.

Finally, our paper also relates to a vast literature on the determinants of PTM. We build on the predictions of a variety of models featuring endogenous markups, and heterogeneous PTM across firms. In these models, the perceived price elasticity of demand faced by each firm varies with its market share, making optimal markups variable and related to firm size. ${ }^{10}$ We discuss

\footnotetext{
${ }^{7}$ Blonigen et al. (2013) estimate a positive but mostly insignificant effect on market power. Konings and Vandebussche (2005) and Pierce (2011) find significant evidence of enhanced market power for EU and US firms respectively, while Nieberding (1999) and Rovegno (2013) find mixed results.

${ }^{8}$ See the recent survey by De Loecker and Van Biesebroeck (forthcoming) which discusses the different methods (production-based or demand-based) which have been used to estimate mark-ups.

${ }^{9}$ See the survey by Goldberg and Knetter (1997).

${ }^{10}$ See Burstein and Gopinath (2014) for a detailed discussion of these models.
} 
how trade policy, by affecting market shares, has an effect on market power and PTM in this framework. Consistent with this class of models, we also show that that PTM is more prevalent for large firms in our sample, a finding that echoes those of Berman et al. (2012) and Amiti et al. $(2014){ }^{11}$

The remainder of the paper is structured as follows. The next section presents our conceptual framework and testable predictions. Section 3 presents our multi-country firm-level dataset. Section 4 provides our baseline empirical framework and estimates the extent of PTM at the firm-level across countries and exporters. Section 5 examines the effects of trade policy on market power and PTM, while Section 6 discusses the channels through which these effects appear to play out. Finally, Section 7 discusses the aggregate implications of our findings and Section 8 concludes.

\section{Conceptual framework}

In this section we present different theories through which heterogenous pricing-to-market can arise and we derive two testable predictions on the expected role of non-tariff measures and tariffs in such models to guide our empirical analysis. To study the effect of trade policy on market power through PTM, we consider a class of models with endogenous and variable markups. In this class of models, PTM - how much firms adjust their markups following variations in the exchange rate - is a function of the elasticity of demand perceived by the firms, i.e. of their unobserved market power. More precisely, PTM is stronger for firms perceiving a lower elasticity of demand and such elasticity varies negatively with the performance of the firm and its market share. We present below three types of models that do generate such heterogenous pricing-to-market and in which the effect of trade policy on market power can be derived. All the models considered here are discussed in Burstein and Gopinath (2014), to which we refer the reader for further details. The online appendix, Section A, contains a more detailed presentation of the predictions arising in one specific model, Atkeson and Burstein (2008). ${ }^{12}$

Market power and pricing-to-market. A first category of models features monopolistic competition and non CES demand (Kimball, 1995, Melitz and Ottaviano, 2008, Bergin and Feenstra, 2001). In such models, pass-through is incomplete because firms adjust their - nonconstant - markups following exchange rate variations. The extent of this adjustment depends on their perceived demand elasticity, which is lower for firms with a lower price. Hence, more performant (large/more productive firms) face a lower elasticity of demand and adjust more their markups following exchange rate changes: they price more to market. A second category of models sticks to the CES assumption and monopolistic competition, but assume additive (per unit) distribution costs in the destination country (Corsetti and Dedola, 2005; Berman et al., 2012). These local costs generate pricing-to-market because they disconnect consumer prices

\footnotetext{
${ }^{11}$ See also the Chatterjee et al. (2013) or Li et al. (2015).

${ }^{12}$ Incomplete pass-through and pricing-to-market can be obtained in other models. For instance, in Alessandria (2004), PTM arises due to the presence of consumer search frictions. Firms dynamic optimization of their customer stock implies a U-shaped relationship between pass-through and market share. Pricing-to-market also arises by modeling consumer search frictions and inventories in Alessandria (2009) and Alessandria and Kaboski (2011). In general, we view the contribution of this section as providing a qualitative guide for our empirical analysis rather than deriving testable predictions that would allow us to discriminate among various theories of pricing-to-market versus others.
} 
from variations in the exchange rates, which reduces the elasticity of demand perceived by the firm to its exporter price. This is all the more the case for high performance exporters, for which the share of those local distribution costs in consumer price is higher as they are more productive and thus charge a lower price. Finally, a third type of models keeps the CES assumption but assumes Cournot competitors faced with a nested CES demand across several sectors (Akteson and Burstein, 2008, Amiti et al., 2014). The elasticity of substitution between sectors is lower than the one inside each industry. Higher performance firms have larger market shares in a given sector and face lower elasticity of demand because they put more weight on firms in other sectors whose products are less substitutable. The elasticity of demand they perceive is the elasticity across sectors, lower than the elasticity within. In the online appendix A we provide a detailed discussion of this model and its implications for the effect of trade policy on market power and PTM. We also perform an exercise in the spirit of Drozd and Nozal (2012) which suggests that the predictions of Akteson and Burstein (2008) are quantitatively consistent with our empirical results.

In sum, in all these models the perceived elasticity of demand - market power - varies negatively with firm performance, size and market shares, and PTM varies negatively with the firms' perceived elasticity of demand. Put differently, the extent of PTM is a measure of market power.

Trade policy, market power and pricing-to-market. In this general framework, trade policy might have two effects on the market structure in the destination market and thus on firms' market power and pricing-to-market. On the one hand, trade policy affects the number of firms serving a destination market, by pushing small firms in or out the market. On the other hand, holding the number of firms constant, trade policy can affect firms' performance, i.e. their size and market shares (an intensive margin effect). Tariffs and NTMs then have distinct effects because they do not involve the same type of costs, and because they either affect all firms in the case of NTMs, or only apply to exporters in the case of tariffs. We now present in more details our testable predictions about the effects of NTMs and tariffs on PTM.

Suppose an origin country (home) in which firms potentially serve two foreign destinations, 1 and 2. Assume that home firms face a fixed cost of exporting which is symmetric across destinations. First, consider the case of NTMs. Assume that both destinations 1 and 2 are tariff-free, but that in destination 2 firms face a non-tariff measure in the form of a fixed cost which forces all firms to use a more capital intensive technology. By the non-discriminatory nature of NTMs this increase in fixed cost affects all operating firms in market 2. The higher fixed cost on destination 2 crowds out small firms, a classic result in heterogeneous firms' models. As destinations 1 and 2 are otherwise identical, this decrease in the number of firms increases the market share of all surviving firms, both foreign and domestic, in destination 2. Surviving firms thus perceive a lower elasticity of demand, which raises the extent of their PTM on market 2. We test the following:

Testable prediction 1 (Non-tariff measures and PTM): If NTMs increase fixed compliance costs for all firms, they reduce the degree of exchange-rate pass-through and raise the extent of pricing to market.

Now consider the case of tariffs. Assume that a firm exporting a product to both destinations faces a tariff in market 2, none in market 1. Except for the tariff in market 2 there is no 
other asymmetric trade cost and the two destinations are identical. Tariffs in destination 2 are ad-valorem and discriminatory, i.e. they apply only to home firms. The effect of such tariffs is isomorphic to an increase in the marginal costs of all home firms exporting to destination 2. Tariffs have thus two effects on market shares: First, they have an extensive margin effect whereby they displace small home competitors in favor of the largest remaining firms, both home and destination 2 firms. This implies that for the remaining home firms the market shares increase. Second, tariffs increase the foreign price of home-produced goods in destination 2, which decreases the demand faced by home firms and their market share. In net, the effect of a tariff in destination 2 on home firms' market share, perceived elasticity of demand and PTM is indeterminate.

Testable prediction 2 (Tariffs and PTM): The effect of tariffs on the degree of exchange-rate pass-through and thus on the extent of pricing to market is indeterminate.

The effect of tariffs on PTM is thus an empirical question. However, a key difference with non-tariff measures is that tariffs are discriminatory in nature while NTMs are not (WTO's national treatment clause). Tariffs are then more likely to displace foreign firms in favor of domestic ones, implying that the intensive margin effect dominates and in net tariffs reduce the market shares of exporters and thus their incentive to engage in PTM. In the empirics, we will verify that this is indeed the case using our large dataset of developing and emerging countries.

Note that our assumption is that NTMs increase fixed compliance costs, however in principle NTMs could also affect variable costs, for instance if firms need to pay a higher price for their inputs. In that case the effect becomes similar to that of a tariff. This would decrease both the number of firms and their size. However, contrary to tariffs, because NTMs are non-discriminatory, the extensive effect might dominate and market power might increase for non-exiting firms - we would observe in this case more PTM. NTMs could also take the form of per unit costs, for instance if firms need to pay inspection costs per unit sold in destination country. In that case, assuming as in Corsetti and Dedola (2005) that these additional per unit costs are paid in the currency of destination 2, the presence of NTMs would now also reduce the firms' perceived elasticity of demand in market 2 . The extensive margin effect together with the effect on the elasticity of demand may likely dominate, leading to more PTM for non-exiters. In both cases, because NTMs increase variable costs, they should affect market power and PTM through the intensive margin of trade. However, in Section 6, we will verify that NTMs are mostly associated with changes at the extensive margins of trade.

Our main objective in this paper is not to study the precise channel through which trade policy affects market power. Rather, our goal is to provide clear-cut evidence about the sign of these theoretically ambiguous effects. Still, our results are informative about the channel. If NTMs affect mostly variable costs, we would expect their effect on PTM to be similar to that of tariffs. The fact that we find a negative effect of tariffs on PTM and a positive one of NTMs is a first indication that the latter are operating mostly through a fixed cost channel. We also discuss in Section 6 a number of additional estimations where we regress various indicators of trade margins (number of exporters, average price and size, concentration indices) on NTMs and 
tariffs to shed some additional light on those channels of transmission. We show in particular that while tariffs are associated with changes in firms' performance at the intensive margin of trade, NTMs are mostly related to indicators at the extensive margin. ${ }^{13}$

\section{$3 \quad$ Data and descriptive statistics}

Testing our predictions requires gathering three main types of data: (i) firm-level data on export flows, (ii) macroeconomic data and (iii) trade policy variables. Note that when testing the impact of trade policy on market power, the use of firm-level data is key because it enables us to control for firm characteristics which affect their reaction to exchange rate variations (e.g. marginal costs, size or other firm characteristics such as financial constraints) and can be correlated with trade protection.

\subsection{Firm-level trade data}

Our data was obtained from the customs administrations of twelve developing countries. Data for Kenya, Rwanda, Tanzania and Uganda was obtained by the International Growth Center and data for Bangladesh, Chile, Jordan, Kuwait, Lebanon, Mexico, Morocco, and Yemen was obtained by the Trade and Integration Unit of the World Bank Research Department, as part of the Exporters Dynamics Database (EDD) project described in Cebeci et al. (2012). Pooling data from different developing countries allows us to provide results on regions which have received little attention so far. The structure of our dataset also allows us to observe countries with different development levels, facing different trade policy arrangements (in particular preferential tariffs), which implies a gain in statistical power.

For each country, all export transactions are covered over a certain time period (see Table 1). For each firm and year, the data includes a firm identifier, as well as the value (in local currency) and quantity (expressed in kilograms) sold by the firm for each destination country and HS product (at country-specific HS8-equivalent levels). ${ }^{14}$ For each firm-destination-productyear, unit values are computed as the ratio of export value to quantity. Note that unit values are an imprecise proxy for prices because there may be more than one distinct product within a 8-digit code. Prices changes may be due to compositional changes within a product code or due to errors in measuring quantities. We clean the data in a number of ways which helps mitigate the latter issue. First, we exclude mineral products (chapters HS 25 to 27) and services (chapters HS 98 to 99). ${ }^{15}$ Second, we keep only flows over a thousand USD. Third, we follow Amiti et al. (2014) and restrict the sample to 8-digit products which fall in the main 2-digit sector of the firm, and drop observations when unit values changes are above $200 \%$ or below $-67 \%$. We will also systematically report robustness exercises in which instead we drop the top and bottom $1 \%$ of observations in terms of changes of unit values, percentiles being computed at the level of the

\footnotetext{
${ }^{13}$ The theories mentioned in this section are heterogeneous firms models where each firm produces a single good. It might be the case that trade policy has an impact on PTM through their effect on multi-product firms. We come back to this point when discussing our empirical results in Section 6 .

${ }^{14}$ Product classifications are not harmonized between countries at sub-HS6 levels of disaggregation (HS8 or HS10). This is not a problem in our estimations as all regressions have fixed effects at the firm-destination-product level. However, for comparability of descriptive statistics, we aggregate products up to the harmonized HS6 level.

${ }^{15}$ Mineral and primary products are commonly disregarded due to large and sudden fluctuations in international prices and associated terms-of-trade shocks, arbitrarily driving the export performance.
} 
2-digit sector and exporting country. Table 1 gives basic information on final sample size and period by origin country.

Table 1: Sample characteristics

\begin{tabular}{lcccccccc}
\hline \hline Country & Period & \# observations & Obs./year & \# firms & \# dest. & \# products & dest./firm & prod./firm \\
\hline Bangladesh & $2006-11$ & 116,531 & 19,901 & 7423 & 158 & 821 & 10.7 & 8.1 \\
Chile & $2004-09$ & 171,212 & 28,900 & 6174 & 155 & 2318 & 16.1 & 9.2 \\
Jordan & $2004-11$ & 15,736 & 2,142 & 1630 & 133 & 808 & 10.4 & 4.6 \\
Kenya & $2006-11$ & 26,062 & 4,782 & 2501 & 136 & 1442 & 9.6 & 13.0 \\
Kuwait & $2009-10$ & 1,176 & 601 & 412 & 56 & 325 & 8.0 & 23.3 \\
Lebanon & $2009-10$ & 15,717 & 7,859 & 2221 & 129 & 1101 & 12.1 & 29.6 \\
Mexico & $2003-06$ & 199,942 & 50,834 & 26760 & 151 & 3541 & 8.9 & 21.7 \\
Morocco & $2003-10$ & 91,606 & 11,467 & 5934 & 148 & 1715 & 8.0 & 11.6 \\
Rwanda & $2006-11$ & 613 & 119 & 207 & 36 & 83 & 5.2 & 2.9 \\
Tanzania & $2006-11$ & 4,660 & 868 & 820 & 94 & 483 & 7.5 & 5.6 \\
Uganda & $2005-11$ & 4,129 & 655 & 592 & 77 & 363 & 7.9 & 5.7 \\
Yemen & $2007-10$ & 1,182 & 404 & 387 & 52 & 157 & 6.9 & 9.0 \\
\hline \hline
\end{tabular}

For comparability of statistics, in this table only products are defined at the six-digit level of the Harmonized System.

The sample is dominated by four countries, Bangladesh, Chile, Mexico and Morocco, in terms of transactions (both total and yearly) and number of firms. In the empirical analysis we will report our results on the entire sample as well as split by origin country. All origin countries have diversified destination portfolios, and the total number of HS6 products exported in a year ranges between 83 (Rwanda) and 3,541 (Mexico) out of a notional total of about nearly 6,000 HS6 lines. Sub-Saharan African firms are less diversified on average in terms of both number of destinations and products. Differences in terms of diversification are particularly important in terms of number of products (total or averaged by firm).

\subsection{Country-level variables}

Exchange rates vis-a-vis the U.S. dollar are yearly averages from the IMF's International Financial Statistics (IFS) and are deflated by consumer price indices to obtain annual real exchange rates (RER). Exchange rates are all expressed in local currency units (LCU) per dollar in the IFS. Let $e_{o t}$ and $e_{d t}$ be respectively the origin and destination countries' exchange rates in LCU per dollar in year $t$, and $P_{o t}$ and $P_{d t}$ their consumer price indices. ${ }^{16}$ Let $e_{o d t}$ be the average exchange rate between the origin and destination currencies in year $t$, and let $e_{\text {odt }}^{U S}$ be the average real exchange rate between the destination and the USD in year $t$. Our bilateral exchange rate variables in logs are defined as follows:

$$
\begin{gathered}
\ln \left(e_{o d t}\right)=\ln \left(\frac{e_{o t} / P_{o t}}{e_{d t} / P_{d t}}\right)=\ln \left(\frac{e_{o t}}{e_{d t}}\right)-\ln \left(\frac{P_{o t}}{P_{d t}}\right) \\
\ln \left(e_{o d t}^{U S D}\right)=\ln \left(\frac{1 / P_{o t}}{e_{d t} / P_{d t}}\right)=\ln \left(\frac{1}{e_{d t}}\right)-\ln \left(\frac{P_{o t}}{P_{d t}}\right) .
\end{gathered}
$$

Finally, GDP data are from the World Bank's World Development Indicators (WDI).

\footnotetext{
${ }^{16}$ In our baseline estimations, we have dropped the top percentile of country-pairs in terms of variance of bilateral real exchange rates. Dropping these countries which display extreme price variations (generally countries with hyperinflation) limits measurement error and only drops 0.07 percent of total trade value.
} 


\subsection{Trade policy variables}

We use data on both tariffs and non-tariff measures. For tariffs, we use data on Most Favored Nation (MFN) and preferential tariffs at the HS6 level from TRAINS. For each origindestination-product-year (odpt) quadruplet, we compute the bilateral applied tariff. As we are mostly interested in the role played by differences in trade policy across markets, rather than in the effect of variations in trade policy in a given market over time, we also compute the average bilateral applied tariff over the period. This allows us to smooth out missing values without much loss of information. In the empirical analysis we will show that our results are robust to using time-varying bilateral tariffs.

For non-tariff measures we use ad-valorem equivalents (AVEs) at the destination countryproduct level estimated in Cadot and Gourdon (2014, 2016). The Ad-valorem equivalents were computed for 45 countries and three types of measures, type-A measures (SPS), type-B measures (TBT), and "other" measures (essentially quantitative restrictions). ${ }^{17}$ Section B.1 of the online appendix provides more information on the NTM source data and how they were converted into estimated AVEs.

In Section B.2 we provide additional additional descriptive statistics on our trade policy measures. The bulk of the variations in NTM AVEs (more than 80\%) is attributable to the application of SPS and TBT regulations. Table A.1 shows the (unweighted) average levels of bilateral applied tariffs and NTMs AVEs for the 45 countries covered by both tariff and NTM data. The lowest levels of tariffs are observed in developed countries (e.g. $0.8 \%$ in Japan). NTM AVEs also differ across countries, China having the highest (25\%), which seems to accord with anecdotal evidence of trade-restrictive application of regulatory measures. Countries with similar regulations (e.g. members of the European Union) may nevertheless have different AVEs if they enforce them differently, which is the case for some of the Eastern European members (e.g. Hungary vs. the Czech Republic). Note that while some countries are characterized by high levels of both NTMs and tariffs, the overall correlation between the two is not statistically significant at common confidence levels.

The online appendix discusses other features of the NTMs and tariffs data. We show for instance that tariffs and NTMs data are observed in all 2-digit HS sections, with a larger coverage for tariffs (Table A.2). Different types of NTMs affect different sectors: SPS measures mostly impact animal, vegetable and processed food products, while TBT measures mostly affect manufactured products such as textile, footwear or machinery (Table A.3). We also show in Figure A.1 that the sample for which trade policy data (and especially NTM) is comparable to the rest of the sample in terms of market structure.

\subsection{Additional data}

In our robustness exercises we use additional information on the characteristics of the products (manufacturing, consumer good, differentiated or homogenous), and of the destination countries (gravity type variables including distance, income level, market potential information). We also use aggregated trade data to replicate our analysis at the country-pair-product level. These data

\footnotetext{
${ }^{17}$ These include for e.g. trade-related investment measures or intellectual property, although data on those is very scant. For more information on the MAST nomenclature, see: http://unctad.org/en/PublicationsLibrary/ditctab20122_en.pdf.
} 
and their sources are detailed in the corresponding section as well as in the online appendix Section B.

\subsection{Descriptive statistics}

Table 2 shows descriptive statistics for the variables used in the regressions (see online appendix Section B for additional statistics). Our final sample contains around 55,000 firms. Unsurprisingly, trade-policy variables have the largest proportion of missing values. Both tariffs and the estimated ad valorem equivalents of NTM are low around $5 \%$ to $7 \%$ on average. ${ }^{18}$ The median firm in our sample exports 2 HS 8-digit products and serves 1 destination against 6 products and 3 destinations for the average firm. This skewness in the distribution of products and destinations is consistent with stylized facts documented by the literature over the last decade: most exporters export only one product to a single destination and exports are dominated by a few very large, multi-products, multi-destinations firms (see for instance Mayer and Ottaviano, 2007). ${ }^{19}$

Table 2: Descriptive statistics

\begin{tabular}{lcccccc}
\hline \hline & Obs. & Mean & S.D. & Q1 & Median & Q3 \\
\hline & & & & & & \\
unit value (USD) & 648,566 & 835.14 & $8.70 \mathrm{E}+04$ & 2.01 & 6.28 & 19.30 \\
ln unit value (LCU) & 648,452 & 5.88 & 2.43 & 4.38 & 6.16 & 7.31 \\
\# products (firm, $t_{0}$ ) & 648,566 & 32.51 & 293.08 & 2.00 & 6.00 & 14.00 \\
bilateral RER (USD-dest.) & 636,424 & 0.72 & 0.57 & 0.13 & 0.87 & 1.09 \\
bilateral RER (orig.-dest.) & 636,306 & 140.17 & 427.07 & 7.27 & 11.25 & 77.29 \\
GDP per cap. (constant 2000 USD) & 636,817 & $2.60 \mathrm{E}+04$ & $1.49 \mathrm{E}+04$ & $9.63 \mathrm{E}+03$ & $3.00 \mathrm{E}+04$ & $4.06 \mathrm{E}+04$ \\
GDP (constant 2000 USD) & 642,489 & $3.52 \mathrm{E}+12$ & $4.91 \mathrm{E}+12$ & $1.32 \mathrm{E}+11$ & $1.09 \mathrm{E}+12$ & $2.99 \mathrm{E}+12$ \\
Foreign applied tariff & 595,368 & 0.055 & 0.136 & 0.00 & 0.01 & 0.09 \\
non-tariff measure (NTM AVE) & 135,584 & 0.08 & 0.31 & 0.00 & 0.00 & 0.15 \\
SPS AVE & 135,584 & 0.01 & 0.24 & 0.00 & 0.00 & 0.00 \\
TBT AVE & 135,584 & 0.04 & 0.19 & 0.00 & 0.00 & 0.00 \\
other NTM AVE & 135,584 & 0.03 & 0.20 & 0.00 & 0.00 & 0.00 \\
\hline \hline
\end{tabular}

The number of products and destinations are computed for each firm in the first year it enters the dataset. GDP per capita is reported for the destination country. Foreign import tariffs are computed as the average over the period of the corresponding country-pair-product-year applied tariffs in order to smooth out missing values. For non-tariff measures we use ad-valorem equivalents (AVEs) at the destination country-product level estimated from Cadot and Gourdon $(2014,2016)$. Products are defined at the six-digit level of the Harmonized System.

\section{Pass-through across countries and firms}

In this section, we empirically test on our data whether exchange rate pass-through is incomplete, implying that firms price to market, and that pass-through decreases with firm size, implying that larger firms price more to market. These results, which are predicted by the models reviewed in Section 2, have been documented for other countries, but checking that they hold on our sample is an important first step as our dataset comprises countries of various levels of development, including low income ones in which firms might not necessarily price to market.

\footnotetext{
${ }^{18}$ These numbers are lower than the average levels of protection displayed in Table A.1 in the appendix, which was expected as high levels of protection deter trade and are therefore less likely to be observed in our final dataset.

${ }^{19}$ In Table 2, the median numbers of (HS6) products and destinations appear respectively as 6 and 4 . This reflects multiple counting of multi-product multi-destinations exporters at the level of the unit of observation (firm-destination-product).
} 


\subsection{Econometric strategy}

Average PTM. Let us denote by $\ln \mathrm{UV}_{f d p t}^{U S D}$ the $\log$ of firm $f$ 's producer price for a 8-digit product $p$ exported to destination $d$ in year $t$, proxied by its FOB unit value and expressed in USD. ${ }^{20}$ Let $e_{\text {odt }}^{U S}$ be the average real exchange rate between the destination and the USD in year $t$ as defined in equation (2). Finally, let $\mathbf{x}_{\mathbf{d t}}$ be a set of time-varying destination specific controls, including the destination's GDP per capita and other controls used in our robustness exercises. Our baseline empirical specification estimates the effect of changes in the real exchange rate on $\ln \mathrm{UV}_{f d p t}^{U S D}$, within firm-destination-product triplets over time:

$$
\ln \mathrm{UV}_{f d p t}^{U S D}=\alpha \ln e_{o d t}^{U S D}+\mathbf{x}_{\mathbf{d t}}^{\prime} \lambda+\mathbf{F E}_{f p d}+\mathbf{F E}_{o t}+\varepsilon_{f d p t}
$$

where $\mathbf{F E}_{f d p}$ and $\mathbf{F} \mathbf{E}_{o t}$ are respectively firm $\times$ destination $\times$ product and origin $\times$ year fixed effects. In equation (3), an increase in $e_{o d t}^{U S D}$ is a depreciation of the USD, which we interpret as a depreciation in the exporter's pricing currency (we come back below to the issue of currency denomination of prices and exchange rates in our estimated equations). The coefficient of interest $\alpha$ is the elasticity of export prices to changes in the destination's exchange rate and maps one-toone into an exchange rate pass-through elasticity into USD prices (pass-through is complete when $\alpha=0$ and is zero when $\alpha=1) \cdot{ }^{21}$ Equation (3), as the rest of the specifications, is estimated by OLS with robust standard errors clustered at the dyad-product-year level. We will also report specifications using alternative clustering strategies (Section C.9).

$\mathbf{F E}_{f p d}$ accounts for all time-invariant firm, product or destination characteristics that might affect prices. $\mathbf{F E}_{o t}$ captures changes in economic conditions, in particular changes in costs at the origin country level - for instance supply shocks affecting prices across firms and correlated with exchange rates. We also systematically report results of specifications that include fixed effects in the firm $\times$ product $\times$ year dimension, i.e. that capture entirely changes in costs at the firm-product level: ${ }^{22}$

$$
\ln \mathrm{UV}_{f d p t}^{U S D}=\beta_{1} \ln e_{o d t}^{U S D}+\mathbf{x}_{\mathbf{d t}}^{\prime} \lambda+\mathbf{F E}_{f p d}+\mathbf{F E}_{f p t}+\varepsilon_{f d p t}
$$

In this case, the effect of exchange rate variations is estimated within firm-product, across destinations. This is a rather demanding specification, as the exchange rate coefficient can only be estimated on the sub-sample of firms exporting the same product to multiple destinations.

Firm size. We next check whether the results documented in the literature that larger firms do

\footnotetext{
${ }^{20}$ Note that as our dataset does not contain information on firm ownership, all firms in our sample are treated as independent entities. Thus in the presence of firm subscripts we omit the origin country subscripts.

${ }^{21}$ Note that $\alpha$ may suffer from attenuation bias due to classical measurement error: because we use annual data, the exchange rates applied in our estimations are (potentially) not exactly the ones actually faced by the firms at the time they export. The only way to solve this issue would be to use higher frequency data which would allow us to match transactions with daily or monthly exchange rates. Indeed, Fosse (2012) shows using Danish data that moving from annual to monthly data increases the elasticity of unit values to the exchange rate (from 0.14 to 0.19 in his case (See also Mallick and Marques, 2010). This might explain why the literature using yearly trade customs data typically finds lower estimates of pass-through than those found in papers using direct price data at a higher frequency (e.g. Gopinath and Itskhoki, 2010).

${ }^{22}$ We use estimations in levels rather than first-difference for three main reasons. First, exchange rate appear to be stationary in our data; second, our data exhibit substantial serial correlation. Third, first differences can lead to more attenuation bias due to measurement error in exchange rate variables. Section C.15 of the online appendix discusses these issues in details and provides alternative results in differences.
} 
more PTM also hold in our data. We augment specifications (3) and (4) with an interaction term between the exchange rate and a proxy for firm size. Our specification becomes:

$$
\ln \mathrm{UV}_{f d p t}^{U S D}=\ln e_{o d t}^{U S D}\left(\alpha+\beta \operatorname{Size}_{f 0}\right)+\mathbf{x}_{\mathbf{d t}}^{\prime} \lambda+\mathbf{F E}+\varepsilon_{f d p t}
$$

where $\mathbf{F E}$ includes, firm $\times$ product $\times$ destination fixed effects and either origin $\times$ year or firm $\times$ product $\times$ year fixed effects. While very large, our dataset is relatively poor in covariates as it contains no firm characteristics such as employment or value added. Thus, we rely on proxies for the identification of the effect of firm productivity or size on PTM. In the literature, product scope is the firm-level observable that correlates most closely across firms with productivity. As variations in firm performance and prices may be simultaneously affected by omitted variables, we use beginning-of-period values. In our baseline estimations, Size $_{f 0}$ is therefore the log of the total number of products sold by the firm in the first year it enters our sample. We expect $\beta$ to be positive following our theoretical discussion.

Currency denomination. All our baseline specifications are run in USD. Thus, we assume a priori that transactions in our sample are denominated in USD. Yet, in principle, equations (3) to (7) could be estimated using the exchange rate between the origin and destination currencies and unit values expressed in the currency of the exporting country. In practice, in our data, a large share of the transactions is likely to be denominated in USD. Contrary to most of the literature that focuses on developed countries such as the US, Belgium or France, our sample of countries includes firms that mostly price in dollars (Gopinath, 2015). For instance, this is the case of Chile, where firms mostly invoice using USD while the Chilean peso is hardly ever used (Cravino, 2017). Similarly in Algeria 99\% of exports are invoiced in USD (Gopinath 2015). While our baseline analysis is run in USD, we will systematically report specifications in domestic currency in the online appendix. The results look extremely similar. This is not surprising as our estimations include origin $\times$ year or firm $\times$ product $\times$ year fixed effects. These capture changes in the exchange rate between the origin country and the USD: what remain in the estimations are the variations in the exchange rate between the destination and the USD. Put differently, given our fixed effects, the exchange rates defined in equations (1) and (2) are identical. However, because in most of our estimations the coefficient of interest is that of an interaction term, the two approaches are not strictly equivalent.

\subsection{Results}

Table 3, columns (1) to (7) reports baseline least-squares estimates of equation (3) for the whole sample as well as for separate regions and countries. ${ }^{23}$ All specifications control for firm $\times$ product $\times$ destination and origin $\times$ year fixed effects (equation (3)). We also replicate Table 3 replacing the latter set of fixed effects with firm $\times$ product $\times$ year fixed effects (equation (4)). To conserve space the results are reported in Table A.6 of the online appendix Section C.1. On the whole sample the elasticity of the exporter price to the log of the bilateral RER is positive and significant and implies that the average firm in our sample raises its price by $1.4 \%$ (respectively

\footnotetext{
${ }^{23}$ Note that in all tables, the number of observations varies depending on the dimensions of fixed effects included, as observations perfectly predicted by the fixed effects (singletons) are dropped.
} 
$0.9 \%$ ) following a $10 \%$ depreciation of its home currency in column (1), Table 3 (resp. Table A.6). This elasticity is quantitatively close to the estimates reported in the literature on industrial and emerging countries, which typically lie between 0.05 and $0.2 .{ }^{24}$ Thus, although our elasticities are estimated on a sample of developing countries, we find a degree of exchange rate pass-through which is very much consistent with those found for industrial countries. Moreover, like those found in the existing literature, our estimates also reflect limited PTM on average and very high levels of pass-through into export price ( $86 \%$ in column 1, Table 3). The estimated elasticities might be low due to measurement error arising from using annual data (Fosse, 2012). An alternative explanation is that these firm-level estimates hide a great deal of heterogeneity. If large firms adjust more to exchange rate variations at the price margin pass-through may be lower on aggregate.

Table 3: Pricing-to-market: Baseline

\begin{tabular}{|c|c|c|c|c|c|c|c|c|}
\hline & (1) & $(2)$ & $(3)$ & $(4)$ & $(5)$ & $(6)$ & $(7)$ & $(8)$ \\
\hline $\begin{array}{l}\text { Dep. var. } \\
\text { Exporting countries }\end{array}$ & All & Excl. Mexico & $\mathrm{EAC}$ & $\begin{array}{l}\text { ln unit } \\
\text { MENA }\end{array}$ & $\begin{array}{l}\text { values } \\
\text { Bangladesh }\end{array}$ & Chile & Mexico & All \\
\hline ln RER & $\begin{array}{c}0.138^{a} \\
(0.013)\end{array}$ & $\begin{array}{c}0.137^{a} \\
(0.014)\end{array}$ & $\begin{array}{c}0.297^{a} \\
(0.074)\end{array}$ & $\begin{array}{c}0.050 \\
(0.038)\end{array}$ & $\begin{array}{c}0.091^{a} \\
(0.035)\end{array}$ & $\begin{array}{c}0.147^{a} \\
(0.017)\end{array}$ & $\begin{array}{c}0.152^{a} \\
(0.032)\end{array}$ & $\begin{array}{c}0.056^{a} \\
(0.021)\end{array}$ \\
\hline$\times \ln \left(\#\right.$ product $\left._{t 0}\right)$ & & & & & & & & $\begin{array}{l}0.044^{a} \\
(0.008)\end{array}$ \\
\hline $\ln ($ dest. GDP/cap) & $\begin{array}{c}0.064^{a} \\
(0.024)\end{array}$ & $\begin{array}{c}0.043^{c} \\
(0.026)\end{array}$ & $\begin{array}{c}-0.151^{b} \\
(0.073)\end{array}$ & $\begin{array}{c}0.042 \\
(0.045)\end{array}$ & $\begin{array}{c}0.057 \\
(0.078)\end{array}$ & $\begin{array}{c}0.083^{b} \\
(0.034)\end{array}$ & $\begin{array}{c}0.240^{a} \\
(0.069)\end{array}$ & $\begin{array}{c}0.068^{a} \\
(0.024)\end{array}$ \\
\hline Observations & 495147 & 349302 & 25666 & 97631 & 86669 & 139336 & 145845 & 495147 \\
\hline Adj. $R^{2}$ & 0.979 & 0.975 & 0.960 & 0.975 & 0.928 & 0.980 & 0.984 & 0.979 \\
\hline Firm $\times$ product $\times$ dest. FE & Yes & Yes & Yes & Yes & Yes & Yes & Yes & Yes \\
\hline Origin $\times$ year $\mathrm{FE}$ & Yes & Yes & Yes & Yes & Yes & Yes & Yes & Yes \\
\hline
\end{tabular}

${ }^{c}$ significant at $10 \% ;^{b}$ significant at $5 \% ;^{a}$ significant at $1 \%$. Standard errors clustered by product-origin-destination-year are in parentheses Unit values are expressed in USD. In RER is the real exchange rate of the destination country vis-a-vis the USD as defined in equation (2). $\ln \left(\# \operatorname{product}_{t 0}\right)$ is the total number of products exported by the firm at the beginning of the period. A product is defined at the 8 digit level. Observations perfectly predicted by the fixed effects are dropped.

A second and perhaps more surprising result is that the degree of PTM is very homogenous across origin countries. When significant, the elasticity of producer prices to the exchange rate lies between 0.07 and 0.15, with the only exception of East African countries. Given that the distribution of firms is skewed, if firms react heterogeneously to exchange rates, one would mechanically expect to find low elasticities in firm-level estimations as small firms, which adjust less at the price margin, represent the majority of observations, driving down estimates compared to those obtained on product-level data. This indeed can be seen in column (8), where we add an interaction between the exchange rate and a measure of firm size, the number of product exported by the firm at the beginning of the period (equation (5)). In both Table 3 and Table A.6 the coefficient of this interaction term is positive and significant, suggesting that large firm price more to market. This is consistent with Berman et al. (2012) and Amiti et al. (2014), among others. Quantitatively, the heterogeneity in adjustment is non-negligible. The estimated coefficients in column (8), Table 3 suggest that following a $10 \%$ depreciation of its home currency

\footnotetext{
${ }^{24}$ Around 0.1 in France (Berman et al., 2012); 0.15 in Denmark (Fosse, 2012); 0.2 in Belgium (Amiti et al., 2014) and Brazil (Chatterjee et al., 2013); 0.06 in China (Li et al., 2015).
} 
a firm exporting only one product will raise its price on average by only $0.56 \%$, while a firm selling ten products will raise its price by $1.6 \%$ - three times more. ${ }^{25}$ This heterogeneity is consistent with the prediction of the models reviewed in Section $2 .^{26}$

\section{$5 \quad$ Trade policy and pricing-to-market}

We now turn to the core contribution of the paper and test our predictions relating trade policy measures and the level of PTM (Testable predictions 1 and 2 of Section 2).

\subsection{Econometric strategy}

Non-tariff measures. As discussed earlier, NTMs and tariffs have starkly different effects on market structure. NTMs generate compliance costs for all producers that induce the exit of the smallest ones, raising the market share of all remaining ones, including foreign exporters. In that case, the market power of foreign exporters is enhanced by NTMs which raise their incentive to engage in PTM (Testable prediction 1). To estimate the effect of NTMs on market structure, we augment specifications (3) and (4) with an interaction term between the exchange rate and our measure of NTMs. Our estimating equation becomes:

$$
\ln \mathrm{UV}_{f d p t}^{U S D}=\ln e_{o d t}^{U S D}\left(\alpha+\beta \operatorname{Size}_{f 0}+\gamma \mathrm{NTM}_{d p}\right)+\mathbf{x}_{\mathbf{d t}}^{\prime} \lambda+\mathbf{F E}+\varepsilon_{f d p t}
$$

where $\mathrm{NTM}_{d p}$ is the ad-valorem equivalent of NTMs imposed by destination $d$ on product $p$. FE is defined as before. Unlike tariffs, NTMs are all recorded as "MFN", i.e. applying to all origin countries, a convention which largely reflects the way most of them are administered. ${ }^{27}$ In equation (6), $\gamma>0$ is our test for the combined hypothesis that NTMs are applied in nondiscriminatory fashion but reduce competition increasing the fixed cost of faced by producers.

Applied tariffs. To estimate the impact of tariffs on market structure (Testable prediction 2 ), we interact the exchange rate with the log of bilateral tariffs plus one. We use data on applied tariffs which vary across product-destination cells and take into account all preferential regimes. In order to make the exercise comparable to the one on non-tariff measures, for which we have no time-wise variation, we use a time-wise average of tariffs over the sample period. ${ }^{28}$

\footnotetext{
${ }^{25}$ Section C. 2 of the online appendix shows that the results of Table 3 are similar when an alternative cleaning method is used or when prices are expressed in the exporter's currency. Section C.3 reports estimates of the elasticity of export volumes to exchange rate variations.

${ }^{26}$ In Akteson-Burstein, the relationship between size and PTM is non-monotone in theory, yet among small firms, the larger ones are predicted to do more PTM. As our dataset consists of developing-country exporters, most of which are small on their destination markets, this is what we expect to see in the data. The model also predicts that holding constant the price index in the destination country, the relationship between size and PTM becomes monotonically increasing. We directly test for that by including in our baseline specifications origin $\times$ destination $\times$ product $\times$ year fixed effects. Results are reported and discussed in Section C. 2 of the online appendix.

${ }^{27}$ Whereas applied tariffs are specific to origin-destination dyads, most non-tariff measures, in particular SPS and TBT regulations, are imposed on an "MFN" basis, i.e. specific to a destination and not a dyad. For instance, a maximum residual level of pesticides in horticulture products applies to all imports, not just to imports from a particular country, and, unlike a tariff, will not be relaxed in the presence of a preferential trade agreement.

${ }^{28} \mathrm{An}$ additional reason for doing this is that tariff data contain many missing values; using average values allows maximizing the number of observations. We however provide robustness exercises using time-varying tariffs.
} 
The corresponding estimating equation is:

$$
\ln \mathrm{UV}_{f d p t}^{U S D}=\ln e_{o d t}^{U S D}\left(\alpha+\beta \operatorname{Size}_{f 0}+\theta \operatorname{Tariff}_{o d p}\right)+\mathbf{x}_{\mathbf{d t}}^{\prime} \lambda+\mathbf{F E}+\varepsilon_{f d p t}
$$

where $\mathbf{F E}$ is defined as before and Tariff ${ }_{\text {odp }}$ is the average tariff imposed by destination country $d$ on product $p$ imported from origin $o$ over the period. Prediction 2 implies an ambiguous effect of tariffs on foreign firms market shares and thus on their incentives to engage in PTM. How import tariffs in one destination market affect foreign firms market power is thus an empirical question. However, as previously discussed, since tariffs are discriminatory we would expect their rent-shifting effects to dominate and in net see them erode the market power of foreign exporters. That is, empirically we would expect $\theta$ to be negative.

\subsection{Main results}

NTMs. Table 4 reports estimates from specification (6). In this table as in all the robustness exercises, we present estimations with origin $\times$ year fixed effects (columns 1 to 4 ) or with firm $\times$ product $\times$ year fixed effects (columns 5 to 8 ). The number of observations is much lower than previously due to the incomplete availability of NTMs AVEs. ${ }^{29}$ In spite of the reduced sample size and the attenuation bias due to the fact that AVEs are themselves econometric estimates, the results confirm the hypothesis of non-discrimination-cum-reduced competition. NTM reinforce the market power of non-exiting firms, domestic and foreign exporters alike, and thus their incentive to engage in PTM. As a result, PTM is significantly stronger quantitatively in markets with high levels of NTMs. Specifically, the coefficients on the exchange rate and its interaction with the NTM variable in column (1) suggest that moving from zero to a $10 \%$ ad valorem equivalent raises the price elasticity to exchange rate by a third from $0.5 \%$ to $0.7 \%$. In columns (2) and (3), splitting the sample according to the level of NTMs yields similar results: The exchange rate coefficients is sixty percent larger in countries and sectors belonging to the top quartile of NTMs (column 3) than in those in the first quartile (column 2). Although the coefficients lose in precision and magnitude, the positive impact of NTMs on pricing-to-market is confirmed when we add to the estimations firm $\times$ product $\times$ year.

In our dataset, we can classify NTMs in three categories: SPS, TBT and others, which include Pre-Shipment Inspection, Contingent Measures and Quality Controls. While NTMs and tariffs have starkly different effects on market structure, there is less reason to expect different effects across NTMs categories (in terms of sign). Still, in columns (4) and (8) we examine whether the effect on firm PTM varies across types of NTMs by including separately an interaction term between our exchange rate and these three categories. We find stronger impact of SPS regulations in column (4), but the difference across types of NTMs is much less clear in column (8). In Section C.4 of the online appendix, we further explore the heterogeneity of the effect of NTMs across industries. Given the set of fixed effects used in our estimations, repeating the analysis by HS categories is not feasible due to the limited degrees of freedom. Table A.11 reports the results for three HS sections with the largest number of non-missing NTM data in our sample (HS sections 2, 4 and 11). Our results suggest that fresh products are mostly affected by SPS standards, such

\footnotetext{
${ }^{29}$ We confirmed that our main results of incomplete pass-through still hold despite the lower number of observations by re-estimating column (1) of Table 3 on this smaller sample. Results were unchanged (the exchange rate coefficient is estimated at 0.12 , very close to our baseline of Table 3 ).
} 
as for example pests control or pesticide usage regulations, while processed food products more affected by TBT standards, including for example regulations on residues limits or packaging requirements.

Table 4: Non-tariff measures and pricing-to-market: Baseline

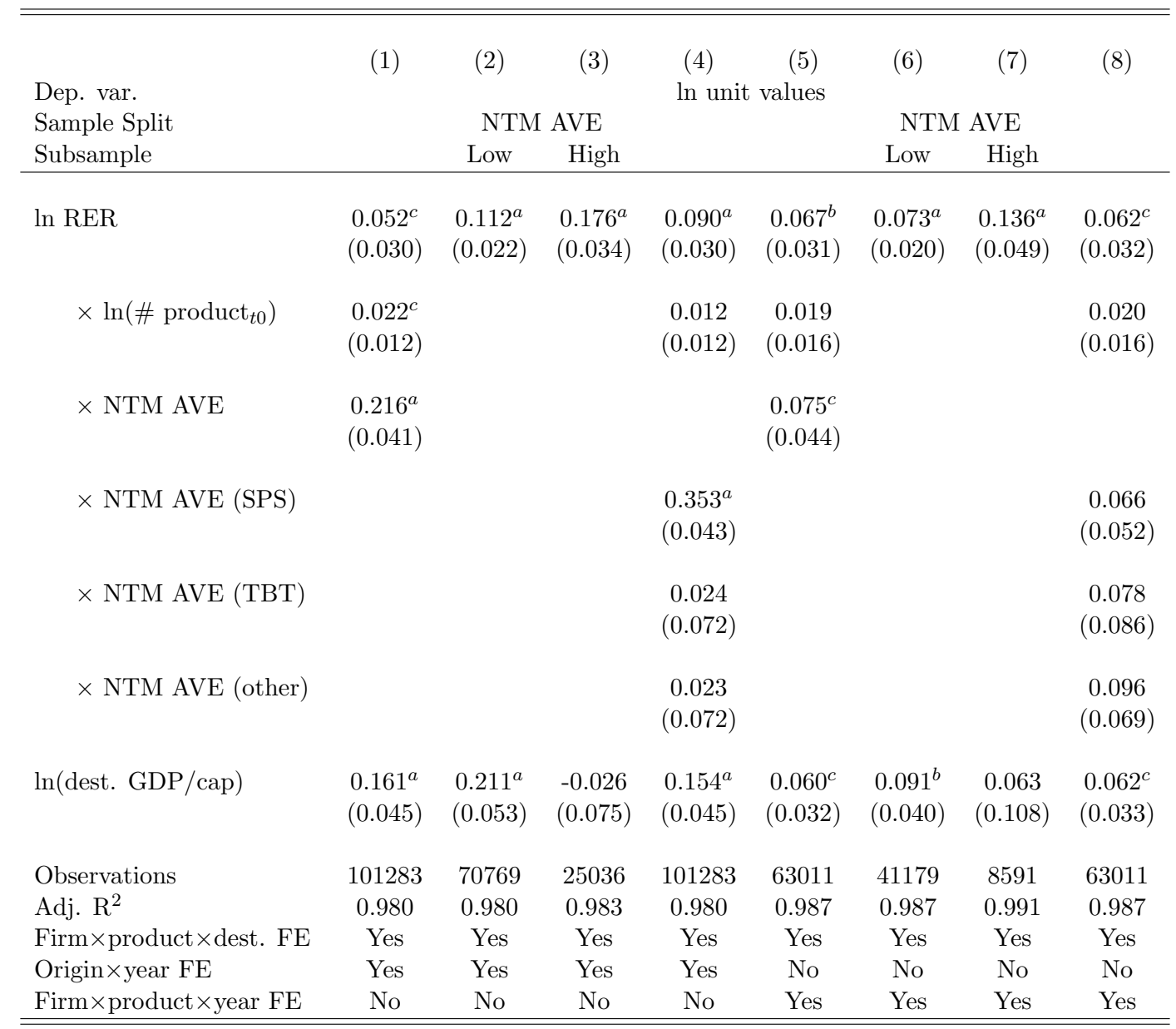

${ }^{c}$ significant at $10 \% ;{ }^{b}$ significant at $5 \% ;{ }^{a}$ significant at $1 \%$. Standard errors clustered by product-origin-destination-year are in parentheses High and Low means respectively above (or equal to) the third quartile or below (or equal to) the first quartile of the corresponding variable ln RER is the real exchange rate of the destination country vis-a-vis the USD. SPS and TBT mean respectively Sanitary and Phyto-Sanitary and Technical Barriers to Trade. $\ln \left(\#\right.$ product $\left._{t 0}\right)$ is the total number of products exported by the firm at the beginning of the period.

Applied tariffs. We now turn to the results on tariffs. Table 5 reports the results. Columns (1) and (4) report estimates of equation (7) with different sets of fixed effects. The coefficient on the interaction term between exchange rate and applied tariffs is negative and highly significant. We find strong support for rent-shifting effects of tariffs, i.e. tariffs reduce the elasticity of homecurrency export prices to the exchange rate, implying a higher pass-through.

How large are the effects? Faced with a $10 \%$ depreciation of its home currency, firm $f$ selling a product tariff-free in a given destination would raise its home-currency price by $0.6-0.7 \%$ (column 1 or 4$)$. Faced with the same depreciation on a destination with a $5 \%$ tariff, it would raise it by only $0.35-0.37 \%$, or about two times less. When the tariff reaches $10-15 \%$, pass-through is complete, i.e. no significant PTM is detected anymore. Similar results are obtained in columns $(2),(3),(5)$ and $(6)$, which report results for destination-product $(d p)$ cells in the highest quartile of tariffs (where they are above $9 \%$ ) vs. the lowest (where they are zero). In the latter, firms 
Table 5: Import tariffs and pricing-to-market: Baseline

\begin{tabular}{|c|c|c|c|c|c|c|}
\hline \multirow{4}{*}{$\begin{array}{l}\text { Dep. var. } \\
\text { Sample Split } \\
\text { Subsample }\end{array}$} & (1) & $(2)$ & $(3)$ & $(4)$ & $(5)$ & $(6)$ \\
\hline & \multicolumn{6}{|c|}{ ln unit values } \\
\hline & \multicolumn{4}{|c|}{ Tariff } & \multicolumn{2}{|c|}{ Tariff } \\
\hline & & Low & High & & Low & High \\
\hline ln RER & $\begin{array}{c}0.067^{a} \\
(0.023)\end{array}$ & $\begin{array}{l}0.178^{a} \\
(0.023)\end{array}$ & $\begin{array}{l}0.076^{a} \\
(0.024)\end{array}$ & $\begin{array}{c}0.057^{b} \\
(0.023)\end{array}$ & $\begin{array}{c}0.127^{a} \\
(0.022)\end{array}$ & $\begin{array}{c}0.045^{c} \\
(0.024)\end{array}$ \\
\hline$\times \ln \left(\#\right.$ product $\left._{t 0}\right)$ & $\begin{array}{l}0.050^{a} \\
(0.008)\end{array}$ & & & $\begin{array}{c}0.022^{b} \\
(0.011)\end{array}$ & & \\
\hline$\times \ln ($ tariff +1$)$ & $\begin{array}{c}-0.646^{a} \\
(0.101)\end{array}$ & & & $\begin{array}{l}-0.401^{a} \\
(0.088)\end{array}$ & & \\
\hline $\ln ($ dest. GDP/cap) & $\begin{array}{l}0.084^{a} \\
(0.025)\end{array}$ & $\begin{array}{c}0.009 \\
(0.052)\end{array}$ & $\begin{array}{c}0.190^{a} \\
(0.043)\end{array}$ & $\begin{array}{c}0.051^{b} \\
(0.020)\end{array}$ & $\begin{array}{l}-0.086^{c} \\
(0.045)\end{array}$ & $\begin{array}{c}0.127^{a} \\
(0.039)\end{array}$ \\
\hline Observations & 456838 & 208269 & 113044 & 273672 & 81739 & 73856 \\
\hline Adj. $R^{2}$ & 0.979 & 0.981 & 0.961 & 0.985 & 0.987 & 0.965 \\
\hline Firm $\times$ product $\times$ dest. FE & Yes & Yes & Yes & Yes & Yes & Yes \\
\hline Origin $\times$ year FE & Yes & Yes & Yes & No & No & No \\
\hline Firm $\times$ product $\times$ year FE & No & No & No & Yes & Yes & Yes \\
\hline
\end{tabular}

${ }^{c}$ significant at $10 \% ;{ }^{b}$ significant at $5 \% ;^{a}$ significant at $1 \%$. Standard errors clustered by product-origin-destination-year are in parentheses High and Low mean respectively above (or equal to) the third quartile or below (or equal to) the first quartile of the corresponding variable. In

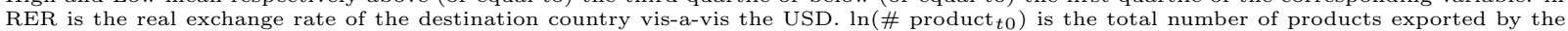
firm at the beginning of the period.

raise their home-currency price by $1.3-1.8 \%$ following a $10 \%$ depreciation. In the former, they raise it by $0.4-0.8 \%$. Thus, tariffs at their current levels have substantial effects on the pricing behaviour of foreign exporters, suggesting that they affect market structure (presumably through rent-shifting effects) in a non-trivial way.

Firm-level quantification. To illustrate the differential effect of tariffs and NTMs on PTM, we compute the predicted degree of PTM for various combinations of tariffs and non tariff measures. The results are shown in Figure 1. The estimates are based on a specification where both tariffs and NTMs are introduced simultaneously (Table 6 in the next section). The online appendix C.5 reports an equivalent using the coefficients from a specification that includes firm $\times$ product $\times$ year fixed effects.

In markets with low-impact NTMs (first three bars on the left), exchange rate pass-through is complete, except in tariff-free markets where it declines slightly to around 90\% (1-0.1). Passthrough becomes strongly incomplete and shrinks to as low as $65 \%(1-0.35)$ in markets with zero tariffs but high-impact NTMs (last three bars on the right). The results shown in online appendix C.5 with firm $\times$ product $\times$ year fixed effect are quantitatively smaller but still sizeable: in markets with zero tariffs and high NTMs, pass-through is estimated at $76 \%$. Overall, tariffs are found to affect the extent of pricing-to-market more than NTMs.

\subsection{Robustness}

Omitted variables. One concern when estimating the effect of our trade policy measures on 
Figure 1: Trade policy and exchange rate pass-through

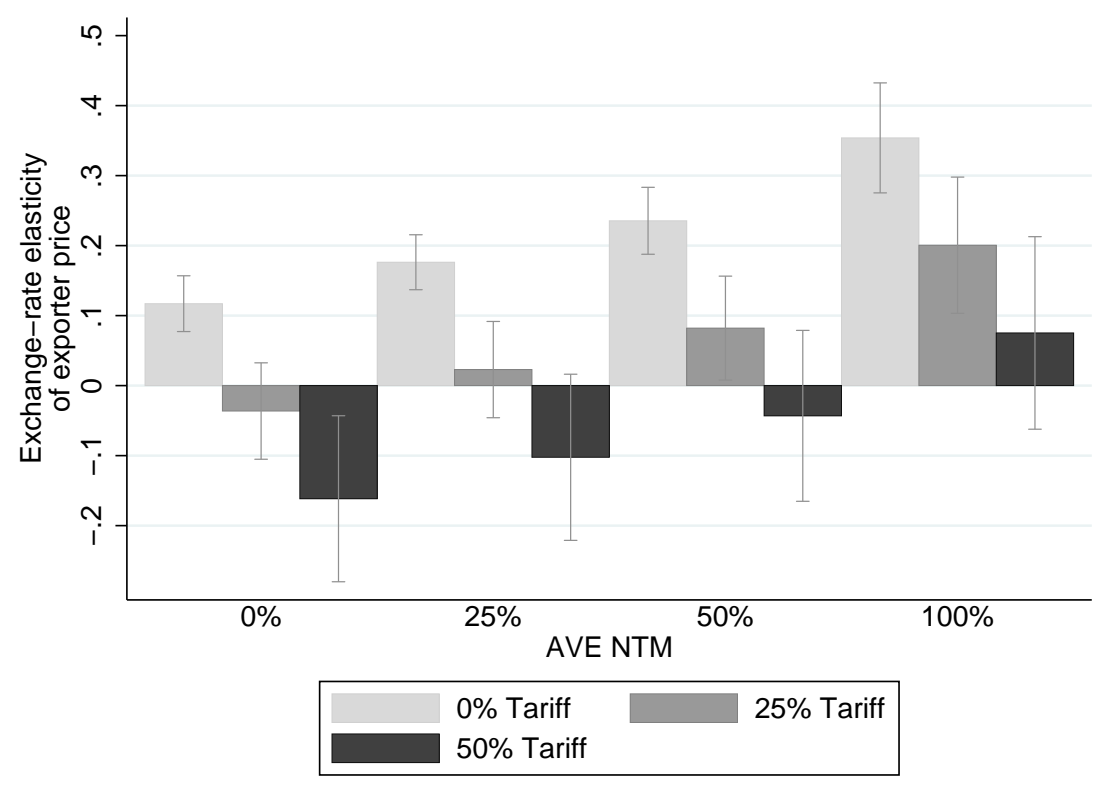

Predicted effects and 95\% confidence bands computed from column (1) of Table 6.

the extent of firm PTM in Tables 4 and 5 is that tariffs and NTMs may be negatively correlated, for instance if countries substitute one instrument for the other. If this was the case, entering each separately in different regressions might lead to an omitted variable bias. In columns (1) and (6) of Table 6, we control for this, including both instruments simultaneously in our regressions; the results are similar. A second, more important issue is that observed trade policy might be correlated with country- or product-specific characteristics that affect pass-through. For instance, NTMs might be systematically higher in more developed countries, and tariffs lower in manufacturing than in agriculture. In Section B.2 of the online appendix, we provide descriptive evidence that this is not the case in our data. Figure A.2 reports no significant correlation between average NTMs levels and characteristics in the destination countries. Similarly, Table A.4 suggests that the levels of NTMs and applied tarrifs are uncorrelated with product characteristics. In Table 6 we nonetheless control for a wide array of variables that might correlate with trade policy and affect PTM. We start by adding interactions between the exchange rate and the destination countries' characteristics such as per capita GDP, GDP, and market potential in columns (2) and (7). In columns (3) and (8) we include interaction terms between the RER variable and a measure of market size varying by product and destination (total imports), as well as a set of standard gravity controls. In columns (4) and (9) we control for interaction terms between the real exchange rate and several product-specific characteristics: dummies for consumer goods (defined according to the Broad Economic Categories classification), manufacturing goods and differentiated goods (defined according to Rauch classification). Finally, in columns (5) and (10) we perform a more extreme exercise and include sets of interactions between the exchange rate and (i) destination group dummies; (ii) origin country dummies; as well as (iii) 2-digit sector dummies. This allows controlling for any time-invariant unobserved destination, origin or product factors that could be 
Table 6: NTMs, Tariffs and pricing-to-market: Robustness

\begin{tabular}{|c|c|c|c|c|c|c|c|c|c|c|}
\hline Dep. var. & $(1)$ & $(2)$ & $(3)$ & (4) & $\begin{array}{l}(5) \\
\ln \text { unit }\end{array}$ & $\begin{array}{c}(6) \\
\text { values }\end{array}$ & $(7)$ & $(8)$ & (9) & $(10)$ \\
\hline $\ln$ RER & $\begin{array}{c}0.078^{b} \\
(0.032)\end{array}$ & $\begin{array}{c}-0.118 \\
(0.392)\end{array}$ & $\begin{array}{c}0.312 \\
(0.258)\end{array}$ & $\begin{array}{l}0.299^{a} \\
(0.053)\end{array}$ & & $\begin{array}{c}0.073^{b} \\
(0.033)\end{array}$ & $\begin{array}{l}1.388^{a} \\
(0.354)\end{array}$ & $\begin{array}{c}0.243 \\
(0.241)\end{array}$ & $\begin{array}{c}0.092 \\
(0.059)\end{array}$ & \\
\hline$\times \ln \left(\# \operatorname{product}_{t 0}\right)$ & $\begin{array}{c}0.020 \\
(0.013)\end{array}$ & $\begin{array}{c}0.022^{c} \\
(0.012)\end{array}$ & $\begin{array}{c}0.020 \\
(0.013)\end{array}$ & $\begin{array}{c}0.033^{a} \\
(0.013)\end{array}$ & $\begin{array}{c}0.024^{c} \\
(0.013)\end{array}$ & $\begin{array}{c}0.017 \\
(0.016)\end{array}$ & $\begin{array}{c}0.018 \\
(0.017)\end{array}$ & $\begin{array}{c}0.020 \\
(0.017)\end{array}$ & $\begin{array}{c}.013 \\
(0.016)\end{array}$ & $\begin{array}{c}0.016 \\
(0.018)\end{array}$ \\
\hline$\times \ln ($ tariff +1$)$ & $\begin{array}{c}-0.679^{a} \\
(0.154)\end{array}$ & $\begin{array}{c}-0.751^{a} \\
(0.162)\end{array}$ & $\begin{array}{c}-0.731^{a} \\
(0.168)\end{array}$ & $\begin{array}{c}-0.487^{a} \\
(0.153)\end{array}$ & $\begin{array}{c}-0.250 \\
(0.164)\end{array}$ & $\begin{array}{c}-0.530^{a} \\
(0.163)\end{array}$ & $\begin{array}{c}-0.535^{a} \\
(0.169)\end{array}$ & $\begin{array}{c}-0.636^{a} \\
(0.173)\end{array}$ & $\begin{array}{c}-0.566^{a} \\
(0.163)\end{array}$ & $\begin{array}{l}-0.248 \\
(0.187)\end{array}$ \\
\hline$\times$ NTM AVE & $\begin{array}{c}0.233^{a} \\
(0.041)\end{array}$ & $\begin{array}{c}0.232^{a} \\
(0.042)\end{array}$ & $\begin{array}{c}0.235^{a} \\
(0.041)\end{array}$ & $\begin{array}{c}0.183^{a} \\
(0.043)\end{array}$ & $\begin{array}{c}0.108^{b} \\
(0.047)\end{array}$ & $\begin{array}{c}0.118^{b} \\
(0.046)\end{array}$ & $\begin{array}{c}0.107^{b} \\
(0.047)\end{array}$ & $\begin{array}{c}0.112^{b} \\
(0.048)\end{array}$ & $\begin{array}{c}0.089^{c} \\
(0.049)\end{array}$ & $\begin{array}{c}0.086^{c} \\
(0.052)\end{array}$ \\
\hline$\times \ln$ (dest. GDP/cap.) & & $\begin{array}{c}-0.070^{c} \\
(0.042)\end{array}$ & & & & & $\begin{array}{c}0.044 \\
(0.037)\end{array}$ & & & \\
\hline$\times \ln ($ dest. GDP $)$ & & $\begin{array}{c}0.015 \\
(0.014)\end{array}$ & & & & & $\begin{array}{c}0.008 \\
(0.012)\end{array}$ & & & \\
\hline$\times \ln ($ dest. Mkt pot. $)$ & & $\begin{array}{c}0.012 \\
(0.028)\end{array}$ & & & & & $\begin{array}{c}-0.093^{a} \\
(0.025)\end{array}$ & & & \\
\hline$\times \ln ($ dest/prod import $)$ & & & $\begin{array}{c}-0.018^{b} \\
(0.008)\end{array}$ & & & & & $\begin{array}{l}-0.003 \\
(0.010)\end{array}$ & & \\
\hline$\times \ln ($ distance $)$ & & & $\begin{array}{c}-0.005 \\
(0.032)\end{array}$ & & & & & $\begin{array}{c}-0.011 \\
(0.029)\end{array}$ & & \\
\hline$\times$ Common language & & & $\begin{array}{c}-0.038 \\
(0.037)\end{array}$ & & & & & $\begin{array}{c}-0.080^{b} \\
(0.035)\end{array}$ & & \\
\hline$\times$ Contiguity & & & $\begin{array}{l}-0.048 \\
(0.070)\end{array}$ & & & & & $\begin{array}{c}0.087 \\
(0.071)\end{array}$ & & \\
\hline$\times$ Consumer good & & & & $\begin{array}{c}-0.173^{a} \\
(0.032)\end{array}$ & & & & & $\begin{array}{c}0.054 \\
(0.038)\end{array}$ & \\
\hline × Manuf. good & & & & $\begin{array}{c}-0.113^{a} \\
(0.039)\end{array}$ & & & & & $\begin{array}{c}-0.061 \\
(0.043)\end{array}$ & \\
\hline$\times$ Diff. good & & & & $\begin{array}{c}-0.108^{a} \\
(0.031)\end{array}$ & & & & & $\begin{array}{c}0.005 \\
(0.038)\end{array}$ & \\
\hline $\ln ($ dest. GDP/cap $)$ & $\begin{array}{l}0.201^{a} \\
(0.048)\end{array}$ & $\begin{array}{c}0.203^{a} \\
(0.050)\end{array}$ & $\begin{array}{c}0.207^{a} \\
(0.050)\end{array}$ & $\begin{array}{c}0.210^{a} \\
(0.049)\end{array}$ & $\begin{array}{c}0.186^{a} \\
(0.048)\end{array}$ & $\begin{array}{c}0.069^{c} \\
(0.035)\end{array}$ & $\begin{array}{c}0.092^{a} \\
(0.036)\end{array}$ & $\begin{array}{c}0.075^{b} \\
(0.036)\end{array}$ & $\begin{array}{c}0.071^{b} \\
(0.036)\end{array}$ & $\begin{array}{c}0.062^{c} \\
(0.035)\end{array}$ \\
\hline Observations & 95056 & 93653 & 91596 & 90292 & 95056 & 58132 & 56976 & 55932 & 55452 & 58132 \\
\hline Adj. $R^{2}$ & 0.980 & 0.980 & 0.980 & 0.976 & 0.981 & 0.987 & 0.987 & 0.987 & 0.984 & 0.987 \\
\hline Firm $\times$ product $\times$ dest. FE & Yes & Yes & Yes & Yes & Yes & Yes & Yes & Yes & Yes & Yes \\
\hline Origin $\times$ year FE & Yes & Yes & Yes & Yes & Yes & No & No & No & No & No \\
\hline Firm $\times$ product $\times$ year FE & No & No & No & No & No & Yes & Yes & Yes & Yes & Yes \\
\hline Additional controls & No & No & No & No & Yes & No & No & No & No & Yes \\
\hline
\end{tabular}
${ }^{c}$ significant at $10 \% ;{ }^{b}$ significant at $5 \% ;^{a}$ significant at $1 \%$. Standard errors clustered by product-origin-destination-year are in parentheses. ln RER is the real exchange rate of the destination country vis-a-vis the USD. Additional controls include additional interaction terms betwee the RER variable and origin, destination groups, and sector (HS2) dummies (hence the RER variable alone drops). All estimations include an interaction term between ln RER and the total number of products exported by the firm at the beginning of the period. Consumer goods and differentiated goods are respectively defined according to the BEC and Rauch classifications. GDP, GDP per capita and total imports (by product) of the destination countries are beginning of the period values. 
correlated with our trade policy variables and affect pricing-to-market.

Overall, main results are largely unaffected throughout. We find weak evidence that pricingto-market tends to be less prevalent in more competitive markets, where firms' market power is lower (col. 7). Regarding product characteristics, when significant, the coefficients on the interaction terms tend to be negative (col. 4), but this result is not robust to the inclusion of firm $\times$ product $\times$ year FE (col. 9), to alternative currency specification (online appendix Section C.8), nor to the use of the full sample of countries, i.e without the NTM data restriction. Taken together our results suggest no significant differences across categories of goods. ${ }^{30}$ Finally, when including a full set of origin, destination group and sector interactions (cols. 5 and 10), although the coefficient on tariffs decreases in size and loses significance, the results are globally consistent with our baseline.

Endogeneous trade policy. A second potential concern is that trade policy may be endogenous to market structure. That is, importing countries might decide to set their levels of NTMs or tariffs depending on the market power of the foreign firms serving their markets. While this concern is mitigated by the fact that we are looking at trade policy in the destination countries, where firms from the set of developing countries in our sample are typically small players, we still provide two robustness checks to ensure that endogenous trade policy does not affect our results. We show that we obtain similar results when we drop from the sample exporting countries with high market shares their destination-product (i.e. exporters that could affect foreign trade policy); and when we use an instrumental variable approach in which NTMs and tariffs in a product-destination are instrumented by the level of NTMs/tariffs set by the same destination on other products. These results are reported and discussed in Section C.6 of the online appendix.

Further robustness. The online appendix, Sections C.7 to C.13, contain additional robustness exercises. These show that the results of Tables 4 to 6 are robust to: (i) the use of an alternative cleaning methods of unit values (Section C.7); (ii) using export-currency denominated specifications (Section C.8); (iii) using alternative clustering strategies (Section C.9); (iv) using alternative measures of tariffs and NTMs (Sections C.10 and C.11); (v) controlling for invoicing currency (Section C.12); (vi) dropping periods or countries characterized by high exchange rate volatility (Section C.13) and (vii) controlling for the lagged exchange rate and its interaction with trade policy (Section C.14). We refer the reader to the corresponding section for further discussion.

\section{A discussion of the mechanisms}

Our results so far suggest that NTMs raise the market power of exporters, while tariffs decrease it. In this section we further examine the mechanisms through which these effects on market structure play out. Prediction 1 in Section 2 states that NTMs raise compliance (fixed) costs, inducing the exit of smaller firms, while leaving the surviving ones, both foreign and domestic, with expanded market shares and unambiguously higher market power. Prediction 2 on the other hand is that tariff decrease the market power of exporters in their destination market because

\footnotetext{
${ }^{30}$ While this might appear surprising at first, these results are consistent with Rollo (2015) who find that firms in Tanzania do significant PTM even - especially - for goods classified as homogeneous. Overall, many so-called primary, homogeneous goods such as coffee are de facto differentiated.
} 
they raise variable costs in a discriminatory fashion. While our PTM results are in line with these interpretations, they are not sufficient to rule our alternative explanations, especially in the case of NTMs. It might indeed be the case that NTMs increase variable costs. This would decrease both the number of firms and their size; contrary to tariffs however, because NTMs are non-discriminatory, the extensive effect might dominate and market power might increase for non-exiting firms - we would observe in this case more PTM. Note that we can already rule out the possibility that NTMs are de facto discriminatory (even if they are not de jure) and affect mostly variable costs: in this case their effect should be the same than that of tariffs, which contradicts our PTM findings.

\subsection{Extensive and intensive margin}

One way to have a closer look at the channels through which trade policy affect PTMs is to run regressions akin to Fernandes et al. (2015) and Fontagné et al. (2015), i.e. to regress measures of the intensive and extensive margins of trade on NTMs and tariffs, either at the firm or at the product-level. To conserve space the results are reported on Table 7 and in Table A.34 of the online appendix Section C.17. In Table 7, we estimate the correlation between our time-invariant measures of NTMs and tariffs and firm-product-destination specific export values, volumes, unit values and import shares. In Table A.34 we aggregate the data at the origin-destination-product level and additionally estimate the link between trade policy measures and aggregated margins of trade - average value, volumes, number of exporters, concentration index and import shares.

Table 7: NTMs, tariffs and exports: Firm-product-destination level

\begin{tabular}{|c|c|c|c|c|c|c|c|c|}
\hline \multirow{3}{*}{$\begin{array}{l}\text { Dep. var. } \\
\text { NTM AVE }\end{array}$} & (1) & $(2)$ & (3) & (4) & $(5)$ & $(6)$ & $(7)$ & $(8)$ \\
\hline & \multicolumn{2}{|c|}{ ln values } & \multicolumn{2}{|c|}{ ln volumes } & \multicolumn{2}{|c|}{ ln unit values } & \multicolumn{2}{|c|}{ Import shares } \\
\hline & $\begin{array}{c}-0.030 \\
(0.035)\end{array}$ & $\begin{array}{c}0.019 \\
(0.036)\end{array}$ & $\begin{array}{c}-0.106^{a} \\
(0.040)\end{array}$ & $\begin{array}{c}-0.018 \\
(0.038)\end{array}$ & $\begin{array}{l}0.075^{a} \\
(0.022)\end{array}$ & $\begin{array}{c}0.040^{a} \\
(0.013)\end{array}$ & $\begin{array}{c}0.002 \\
(0.002)\end{array}$ & $\begin{array}{c}0.008^{a} \\
(0.002)\end{array}$ \\
\hline $\ln ($ tariff +1$)$ & $\begin{array}{r}-0.476^{a} \\
(0.176)\end{array}$ & $\begin{array}{l}-0.483^{a} \\
(0.145)\end{array}$ & $\begin{array}{c}-0.398^{c} \\
(0.216)\end{array}$ & $\begin{array}{l}-0.439^{a} \\
(0.148)\end{array}$ & $\begin{array}{c}-0.089 \\
(0.116)\end{array}$ & $\begin{array}{l}-0.051 \\
(0.041)\end{array}$ & $\begin{array}{l}-0.014^{b} \\
(0.007)\end{array}$ & $\begin{array}{l}-0.013^{b} \\
(0.005)\end{array}$ \\
\hline Observations & 51055 & 41477 & 51055 & 41477 & 51055 & 41477 & 48972 & 39465 \\
\hline Adj. $R^{2}$ & 0.571 & 0.612 & 0.722 & 0.781 & 0.832 & 0.938 & 0.507 & 0.370 \\
\hline Firm $\times$ dest. FE & Yes & No & Yes & No & Yes & No & Yes & No \\
\hline Product FE & Yes & No & Yes & No & Yes & No & Yes & No \\
\hline Firm $\times$ product $F E$ & No & Yes & No & Yes & No & Yes & No & Yes \\
\hline Destination FE & No & Yes & No & Yes & No & Yes & No & Yes \\
\hline
\end{tabular}

${ }^{c}$ significant at $10 \% ;^{b}$ significant at $5 \% ;^{a}$ significant at $1 \%$. Robust standard errors. Values, volumes and unit values are averages over the period of the corresponding firm-destination-product triad and are taken in log. A product is defined at the 6 digit level. Import shares are computed as the share of firm $f$ in destination's $d$ total import of a 4-digit level sector, and are averaged over the period of the corresponding firm-destination-product triad. Observations perfectly predicted by the fixed effects are dropped.

Several interesting results arise. Tariffs exhibit a strong negative correlation with export values and import shares, which entirely comes from a drop in volumes rather than unit values (Table 7). Their effect on the extensive margin is less clear and depends on the set of fixed effects included. When significant, the coefficients show a lower number of exporters but also less concentrated exports (Table A.34). These results are consistent with the theoretical predictions that tariffs negatively affect market shares and market power, mostly through their effect on the intensive margin. 
On the other hand, NTMs tend to be associated with higher unit values and a smaller number of exporters (Table 7 and Table A.34). We do not detect any negative correlation between import shares and NTMs (when significant, coefficients are positive). Finally, Herfindahl indices of export concentration tend to be higher in destination-products faced with stronger NTMs (Table A.34). This again accords well with our interpretation that rather than displacing foreign firms in favor of domestic ones like tariffs, NTMs displace small firms in favor of larger ones, including both domestic firms and foreign exporters. This increases the market power of non-exiters. The fact that we find that NTMs are mostly associated with changes at the extensive margin of trade is also consistent with our working assumption that they mostly increase fixed rather than variable costs.

Our results in Table 7 and Table A.34 are consistent with those in Fernandes et al. (2015) and Fontagné et al. (2015). Fontagné et al. (2015) use French firm-level data to show that SPS concerns raised at the WTO entail compliance costs, raising unit values and inhibiting entry. In Fernandes et al. (2015) the focus is on the impact of a specific type of NTMs, namely pesticide standards, on firm exports of agricultural products. Still, the authors show that more restrictive standards in the importing country relative to the exporting country, lower firms' probability to export as well as their export values and quantities. While these results help understand the mechanisms through which NTMs affect trade, they, however, do not speak directly about their impact on market power, which cannot be directly measured in the absence of information on the entire set of firms, both foreign and domestic. This makes apparent how complementary our approach is to these papers, as it allows us to circumvent this problem and uncover that NTMs have unambiguous and opposite effects to that of tariffs when it comes to market power.

Our interpretation of the effect of NTMs is in terms of compliance costs. An alternative, and empirically undistinguishable interpretation is that higher NTMs, by increasing the quality requirements for products or reducing information frictions, may increase the demand for high quality goods. Therefore, high quality firms raise their market shares and hence their market power in those destinations, while low quality firms disappear. Both interpretations are consistent with our main finding that NTMs raise market power at the firm-level. The fact that unit values are positively correlated with NTMs in Table 7 accords well with the quality-based story.

Finally, the mechanisms we have proposed so far abstract from any within-firm adjustment across products. Because NTMs impose fixed costs per product and firm, in countries with high NTMs multi-product firms may focus on their core product, i.e. the product in which they have the largest market share; this implies that our results could be due to an extensive margin adjustment within firms, across products rather than within sectors, across firms. In Section C.16 of the online appendix we show that our results are not purely driven by multi-product firms' ability to adjust their export portfolio. First, we show that controlling for the number of products exported by the firm leaves our results unchanged. Second, we show that our results still hold when focusing on a sample of single-product firms where such a channel of adjustement is de facto absent.

\subsection{The role of import shares}

An alternative way to test the mechanisms underlying our theoretical predictions is to look at 
market shares. Since we do not have market-share data (which is why we identify market power indirectly through pricing behavior in the first place), we attempt to proxy, albeit very imperfectly, the size of firms through their share of aggregate imports. Import shares are computed over destination $d$ 's total imports of product $p$, obtained from the BACI database, with products defined at the 4-digit level, and are evaluated at the beginning of the period. ${ }^{31}$ Import shares are poor proxies for true market shares given that variations in the sales of domestic firms, which are key for the measurement of rent-shifting effects, are not observed. We try to go around the problem by instrumenting import shares with tariffs and NTMs. That is, our postulate is that the variation of import shares explained by the variation of tariffs and NTMs has something to do with the effect of trade policy on market structure.

This exercise has its limitations. First, we cannot directly instrument a firm's import share with trade-policy instruments because it is absorbed by firm-destination-product fixed effectsonly the interaction with exchange rates can be instrumented. And second, if tariffs and quotas were affecting home-currency producer prices through channels other than market power, they would not be valid instruments; however, this is unlikely given that our prices are demeaned in all key dimensions through fixed effects (for instance, large-country tariff effects on world prices would be washed away by demeaning across destinations). For these reasons, we consider this exercise as a further robustness check on our claim that changes in the pricing behavior of exporters reflect the effect of destination trade policy on market structure.

The results are reported in Table 8. In columns (1) and (4) we first report the results of our baseline specification (equation (3)) where we include an interaction term between the real exchange rate and the firm's average import share in destination-product cell $d, p$, defined as before. The coefficient on the interaction term between import shares and the real exchange rate is positive and statistically significant at the 1 percent level in column (1), a result consistent with Amiti et al. (2014). However the result does not survive the inclusion of $f p t$ fixed effects in column (4). As average import shares are however potentially endogenous (influenced by prices and omitted variables), we instrument their interaction with exchange rate by interaction terms between the exchange rate and our two trade policy measures. We expect firms with larger import shares due to low tariffs or high-impact NTMs to adjust more their prices in response to exchange-rate shocks. This is what we find. ${ }^{32}$ In column (2) we find a positive and significant effect of market share on firm-market specific degree of PTM, when instrumented by trade policy. This effect survives when controlling for firm-product-year fixed effects in column (5). Columns (3) and (6) use product-destination rather than firm-product-destination specific market shares. The coefficients are more precisely estimated in this case, which is to be expected as trade-policy instruments affect all exporters from a given origin country in a symmetric way. Note that in the first stage, only the interaction with tariffs is statistically significant. This might be due to the fact that tariffs vary more, as they are de facto bilateral, contrary to NTMs. In general, our instruments are not very strong because of the insignificance of the NTM interaction in the first stage; as it turns out, the values of the F-stat of the first stage increase to 10-18 (and the second stage results are qualitatively similar) when only tariffs are considered as instruments.

\footnotetext{
${ }^{31}$ See http://www.cepii.fr/CEPII/en/bdd_modele/presentation.asp?id=1.

${ }^{32}$ Trade policy variables also have a direct impact on unit values, but this effect is captured by the firm-productdestination fixed effects, given that we use time-invariant policy measures.
} 
Table 8: Import share, trade policy and pricing-to-market: IV regressions

\begin{tabular}{|c|c|c|c|c|c|c|}
\hline & $(1)$ & $(2)$ & $(3)$ & $(4)$ & $(5)$ & $(6)$ \\
\hline \multicolumn{7}{|l|}{ Dep. var: ln unit value } \\
\hline ln RER & $\begin{array}{c}0.009 \\
(0.022)\end{array}$ & $\begin{array}{l}-0.218^{b} \\
(0.107)\end{array}$ & $\begin{array}{c}-0.337^{b} \\
(0.169)\end{array}$ & $\begin{array}{c}0.056^{b} \\
(0.023)\end{array}$ & $\begin{array}{c}-0.211 \\
(0.178)\end{array}$ & $\begin{array}{l}-0.233 \\
(0.156)\end{array}$ \\
\hline$\times$ import share $f d p$ & $\begin{array}{c}0.431^{a} \\
(0.088)\end{array}$ & $\begin{array}{l}10.623^{a} \\
(3.417)\end{array}$ & & $\begin{array}{c}-0.194^{b} \\
(0.081)\end{array}$ & $\begin{array}{c}9.455^{b} \\
(4.366)\end{array}$ & \\
\hline$\times$ import share ${ }_{\text {odp }}$ & & & $\begin{array}{l}1.568^{a} \\
(0.461)\end{array}$ & & & $\begin{array}{l}1.087^{b} \\
(0.454)\end{array}$ \\
\hline \multicolumn{7}{|c|}{ First stage (dep. var.: ln RER $\times$ import share) } \\
\hline ln RER & & $\begin{array}{l}0.030^{a} \\
(0.007)\end{array}$ & $\begin{array}{l}0.266^{a} \\
(0.042)\end{array}$ & & $\begin{array}{l}0.030^{a} \\
(0.009)\end{array}$ & $\begin{array}{l}0.285^{a} \\
(0.052)\end{array}$ \\
\hline$\times \ln ($ tariff +1$)$ & & $\begin{array}{l}-0.086^{a} \\
(0.025)\end{array}$ & $\begin{array}{r}-0.558^{a} \\
(0.155)\end{array}$ & & $\begin{array}{c}-0.065^{a} \\
(0.024)\end{array}$ & $\begin{array}{r}-0.515^{a} \\
(0.183)\end{array}$ \\
\hline$\times$ NTM AVE & & $\begin{array}{c}0.006 \\
(0.006)\end{array}$ & $\begin{array}{c}0.134 \\
(0.095)\end{array}$ & & $\begin{array}{c}0.002 \\
(0.007)\end{array}$ & $\begin{array}{c}0.124 \\
(0.111)\end{array}$ \\
\hline Observations & 454150 & 92048 & 91040 & 270068 & 55046 & 54747 \\
\hline Hansen overid p-value & - & 0.07 & 0.62 & - & 0.08 & 0.89 \\
\hline F-stat excl. instruments & - & 6.5 & 7.9 & - & 3.7 & 6.1 \\
\hline Firm $\times$ product $\times$ dest. FE & Yes & Yes & Yes & Yes & Yes & Yes \\
\hline Origin $\times$ year FE & Yes & Yes & Yes & No & No & No \\
\hline Firm $\times$ product $\times$ year FE & No & No & No & Yes & Yes & Yes \\
\hline
\end{tabular}

${ }^{c}$ significant at $10 \%{ }^{b}$ significant at $5 \% ;^{a}$ significant at $1 \%$. Robust standard errors clustered by product-origin-destination-year are in parentheses. The Stock and Yogo critical value for weak instrument test based on a $20 \%$ (resp. 10\%) 2SLS bias at the $5 \%$ level of significance is 8.75 (resp. 19.9) in all estimations. Estimations also lrer $\times \ln \left(\#\right.$ product $\left.t_{0}\right)$ and $\ln ($ dest. GDP/cap).

\section{Trade policy and aggregate pass-through}

Up to now our analysis was exclusively performed at the firm-level. Whether the significant firm-level impact of trade policy on pricing-to-market and market power translates into an aggregate impact or not is still unclear. It could be that, for instance, that the largest firms, accounting for the bulk of trade, are not much affected by trade policy; in that case aggregate pass-through would be unaffected. As a first step, in the online appendix C.18 we show that, at the firm-level, the effect of trade policy are stronger for large firms in the case of NTMs, and similar across firms in the case of tariffs.

In this section we test whether our results on the effect of trade policy on market power obtained at the firm-level hold at a more aggregate level. To do so, we perform two additional exercises. We start by replicating our analysis using BACI-COMTRADE data at the HS 6-digit product-country pair level. The results are reported in Table 9 below. At the product-level, we still find that NTMs magnify pricing-to-market while tariffs reduce it. Although the magnitude of the effects is lower than what we found at the firm level, it is still economically meaningful. The coefficient in column (1) suggest that moving from zero to a $10 \%$ ad valorem equivalent NTM raises the price elasticity to exchange rate from $5 \%$ to $6 \%$, i.e. by $20 \%$ (against one third in Table 4). For tariffs, moving from a zero to a $5 \%$ tariff, would reduce the price elasticity to 
Table 9: NTMs, tariffs and pricing-to-market: Product-level results

\begin{tabular}{|c|c|c|c|c|c|c|c|c|}
\hline Dep. var. & $(1)$ & $(2)$ & (3) & $\begin{array}{l}(4) \\
\ln \text { unit }\end{array}$ & $\begin{array}{r}(5) \\
\text { values }\end{array}$ & (6) & $(7)$ & $(8)$ \\
\hline ln RER & $\begin{array}{c}0.108^{a} \\
(0.009)\end{array}$ & $\begin{array}{c}0.051^{a} \\
(0.016)\end{array}$ & $\begin{array}{l}0.121^{a} \\
(0.011)\end{array}$ & $\begin{array}{c}0.050^{a} \\
(0.018)\end{array}$ & $\begin{array}{c}0.109^{a} \\
(0.010)\end{array}$ & $\begin{array}{c}0.019 \\
(0.018)\end{array}$ & $\begin{array}{l}0.126^{a} \\
(0.012)\end{array}$ & $\begin{array}{l}0.037^{c} \\
(0.020)\end{array}$ \\
\hline$\times$ NTM AVE & & $\begin{array}{c}0.096^{b} \\
(0.039)\end{array}$ & & $\begin{array}{c}0.097^{b} \\
(0.039)\end{array}$ & & $\begin{array}{l}0.116^{a} \\
(0.045)\end{array}$ & & $\begin{array}{c}0.125^{a} \\
(0.045)\end{array}$ \\
\hline$\times \ln ($ tariff +1$)$ & & & $\begin{array}{c}-0.235^{a} \\
(0.075)\end{array}$ & $\begin{array}{c}0.015 \\
(0.137)\end{array}$ & & & $\begin{array}{l}-0.340^{a} \\
(0.079)\end{array}$ & $\begin{array}{l}-0.341^{b} \\
(0.155)\end{array}$ \\
\hline $\ln ($ dest. GDP/cap) & $\begin{array}{l}-0.051^{a} \\
(0.017)\end{array}$ & $\begin{array}{c}0.017 \\
(0.038)\end{array}$ & $\begin{array}{r}-0.048^{a} \\
(0.017)\end{array}$ & $\begin{array}{c}0.017 \\
(0.038)\end{array}$ & $\begin{array}{l}-0.010 \\
(0.018)\end{array}$ & $\begin{array}{c}0.028 \\
(0.042)\end{array}$ & $\begin{array}{c}0.005 \\
(0.019)\end{array}$ & $\begin{array}{c}0.033 \\
(0.042)\end{array}$ \\
\hline Observations & 1484792 & 429382 & 1395738 & 427557 & 1395264 & 367012 & 1310037 & 365205 \\
\hline Adj. $R^{2}$ & 0.738 & 0.717 & 0.732 & 0.716 & 0.761 & 0.750 & 0.756 & 0.750 \\
\hline Orig. $\times$ product $\times$ dest. $F E$ & Yes & Yes & Yes & Yes & Yes & Yes & Yes & Yes \\
\hline Origin $\times$ year $\mathrm{FE}$ & Yes & Yes & Yes & Yes & No & No & No & No \\
\hline Origin $\times$ product $\times$ year $\mathrm{FE}$ & No & No & No & No & Yes & Yes & Yes & Yes \\
\hline
\end{tabular}

${ }^{c}$ significant at $10 \% ;^{b}$ significant at $5 \% ;^{a}$ significant at $1 \%$. Unit values computed from BACI at the exporter-importer-HS6 product-year level Standard errors clustered by product-origin-destination-year are in parentheses. In RER is the real exchange rate of the destination country vis-a-vis the USD.

exchange rate by $10 \%$ (against $50 \%$ in Table 5 ) from $1.2 \%$ to $1.1 \%$. Online appendix Section C.19 shows that these results are not specific to our sample of countries: we expand the database for all countries for which tariffs / NTMs are available, i.e. a total of 169 exporters serving 146 destinations (43 in NTM estimations). Despite the very different composition of the sample on the exporter side, the results are similar, both qualitatively and quantitatively (Table A.36).

We next examine the link between trade policy and market power at an even more aggregate level and regress country-level export and import pass-through coefficients on weighted measures of NTMs and tariffs, where the weights are defined according to beginning-of-the-period shares of each country-product in total exports or imports. The aggregate pass-through coefficients come from Bussière et al., (2014), and cover 39 countries including twenty two emerging economies. Despite the very small number of observations at hand, the evidence points to a lower (respectively higher) pass-through in countries with high NTMs (respectively tariffs). These results (reported in Table A.37 in online appendix C.20) are consistent with our findings are the firm-level and suggest that our results have implications all the way up to a very aggregate level.

\section{Concluding remarks}

As recently pointed by Goldberg and Pavcnik (2016), over the last decades the international trade literature has increasingly studied the effects of trade frictions unrelated to trade policy, assuming implicitly that the effects of trade policy were negligible. Our results are very much in line with the conclusions of Goldberg and Pavcnik (2016): trade policy matters, and distinguishing NTMs and tariffs is key. We provide in this paper large-scale evidence that trade policy has strong effects on market power - identified through heterogeneity in PTM behavior - at the firm-level and that the direction of this effect varies with the type of instrument. Exporters faced with tariffs on their destination markets do significantly less PTM, revealing a loss of market power 
consistent with rent-shifting effects. High-impact NTMs, on the other hand, reduce the degree of pass-through of foreign exporters, as if they had more market power.

We thus show that NTMs affect market structure quite differently from tariffs. Although we cannot measure directly firm entry and exit into NTM-ridden markets for lack of time-wise variation in NTMs, our findings are consistent with the following conjecture: NTMs today are largely regulatory interventions (sanitary, technical, etc.). Those interventions require firms to adapt their production technology, which may crowd out the least efficient ones, whether domestic or foreign. More efficient ones, again irrespective of whether they are domestic or foreign, benefit from this change in market structure with expanded market shares.

This result suggests that, from a policy standpoint NTMs might well be viewed as a competitionpolicy issue as much as a trade one. This has implications for policy. For instance, as part of deep-integration schemes under ASEAN and the proposed Trans-Pacific Partnership (TPP), a number of countries in Asia are considering setting up regulatory supervision bodies focused on NTMs. Our approach suggests that the mandate of such bodies should encompass the impact of NTMs on domestic market structure rather than just on trade facilitation. This might be best achieved by merging them with existing competition commissions or giving them authority over both regulatory supervision and competition policy.

\section{References}

[1] Alessandria, George (2004), "International Deviations from the Law of One Price: The Role of Search Frictions and Market Share"; International Economic Review 45, 1263-1291.

[2] Alessandria, George (2009), "Consumer search, price dispersion, and international relative price fluctuations." ; International Economic Review 50, 803-829.

[3] Alessandria, George and Kaboski, J.P. (2011), "Pricing-to-market and the failure of absolute PPP." ; American Economic journal 3, 91-127.

[4] Amiti, Mary, O. Istkhoki. and J. Koning (2014), "Importers, Exporters, and the exchange rate disconnect"; American Economic Review 104, 1942-78.

[5] Anderson, John, and P. Neary. (1994), "Measuring the Restrictiveness of Trade Policy"; World Bank Economic Review 8, 151-169.

[6] Atkeson, Andrew, and A. Burstein (2008), "Trade Costs, Pricing-to-Market, and International Relative Prices"; American Economic Review 98, 1998-2031.

[7] Auer, Raphael, and R. Schoenle (2016), "Market Structure and exchange rate PassThrough"; Journal of International Economics 98, 60-77.

[8] Aw, Bee-Yan (1993), "Price discrimination and markups in export markets"; Journal of International Economics 42, 315-336.

[9] Bergin, P. and Feenstra, R. (2001). "Pricing to market, staggered contracts and real exchange rate perisistence". Journal of International Economics, 54(2), 333-359. 
[10] Berman, Nicolas; P. Martin and T. Mayer (2012), "How do Different Firms React to Exchange rate Changes?"; Quarterly Journal of Economics 127, 437-492.

[11] Bernhofen, Daniel M. , and P. Xu (2000), "Exchange rates and market power: evidence from the petrochemical industry"; Journal of International Economics 52, 283-297.

[12] Blonigen, Bruce, B. Liebman, J. Pierce, and W. Wilson (2013), "Are all trade protection policies created equal? Empirical evidence for nonequivalent market power effects of tariffs and quotas"; Journal of International Economics 89, 369-378.

[13] Burstein, Ariel, and G. Gopinath (2014), "International Prices and Exchange Rates"; in Gita Gopinath, Elhanan Helpman and Kenneth Rogoff, eds., Handbook of International Economics, vol. IV; Amsterdam: North Holland.

[14] Bussière, Matthieu, S. Delle Chiaie and T. Peltonen (2014), "Exchange Rate Pass-Through in the Global Economy: The Role of Emerging Market Economies", IMF Economic Review, vol. 62(1), pages 146-178, April.

[15] Cadot, Olivier, and J. Gourdon (2014), "Assessing the Price-Raising Effect of Non-Tariff Measures in Africa", Journal of African Economies 23, 425-463.

[16] — and - (2016), "Non-tariff measures, preferential trade agreements,and prices: new evidence"; Review of World Economics 152, 227-249.

[17] Carrere, Celine, and J. de Melo (2011), "Non-Tariff Measures : What Do We Know, What Should Be Done?"; Journal of Economic Integration 26, 169-196.

[18] Cebeci, Tolga; A. Fernandes, C. Freund, and M. Pierola (2012), "Exporter dynamics database", World Bank Policy Research working paper 6229; Washington, DC: The World Bank.

[19] Chatterjee, Arpita; R. Dix-Carneiro and J. Vichyanond (2013), "Multi-Product Firms and exchange rate Fluctuations"; American Economic Journal: Economic Policy 5, 77-110.

[20] Corsetti, Giancarlo, and L. Dedola (2005) "A macroeconomic model of international price discrimination," Journal of International Economics 67, 129-155.

[21] Cravino, Javier (2017) "Exchange Rates, Aggregate Productivity and the Currency of Invoicing of International Trade", unpublished manuscript.

[22] De Loecker, Jan, P. Goldberg, A. Khandelwal and N. Pavcnik (2016), "Prices, Markups and Trade Reform"; Econometrica 84, 445-510.

[23] — and J. Van Biesebroeck, "Effect of International Competition on Firm Productivity and Market Power"; forthcoming in The Oxford Handbook of Productivity Analysis.

[24] — , C. Fuss and J. Van Biesebroeck (2014), "International competition and firm performance: Evidence from Belgium", Working Paper Research 269, National Bank of Belgium. 
[25] de Melo, Jaime, and S. Urata (1986), "The influence of increased foreign competition on industrial concentration and profitability"; International Journal of Industrial Organization 4, 287-304.

[26] Drozd, Lukasz and J. Nosal (2012), "Pricing To Market In Business Cycle Models"; Meeting Papers 1108, Society for Economic Dynamics.

[27] Edmond, Chris; V. Midrigan, and D. Yi Xu (2018), "How costly are markups? "; NBER Working Paper 24800.

[28] Feenstra, Robert (1984), "Voluntary Export Restraints in U.S. Autos, 1980-81: Quality, Employment, and Welfare Effects"; in Robert E. Baldwin and Anne O. Krueger (eds.), The Structure and Evolution of Recent U.S. Trade Policy; University of Chicago Press.

[29] —; J. Gagnon and M. Knetter (1996), "Market Share And exchange rate Pass-Through In World Automobile Trade"; Journal of International Economics 40, 187-207.

[30] Fernandes, Ana M., E. Ferro and J.S. Wilson (2015), "Product Standards and Firms' Export Decisions"; World Bank Policy Research Working Paper 7315; Washington, DC: The World Bank.

[31] Fontagné, Lionel, G. Orefice, R. Piermartini and N. Rocha (2015), "Product standards and margins of trade: Firm-level evidence"; Journal of International Economics 97, 29-44.

[32] Fontagné, Lionel and G. Orefice (2018), "Let's try next door: Technical Barriers to Trade and multi-destination firms"; European Economic Review 101, 643-663.

[33] Fosse, Henrik (2012), "Exporter Price Response to Exchange Rate Changes", Working Paper, Copenhagen Business School.

[34] Goldberg, Pinelopi, and M. Knetter (1997), "Goods Prices and Exchange Rates: What Have We Learned?"; Journal of Economic Literature 35, 1243-1272.

[35] — and - (1999), "Measuring the intensity of competition in export markets"; Journal of International Economics 47, 27-60.

[36] Goldberg, Pinelopi, and N. Pavcnik (2016), "The effect of trade policy", in Kyle Bagwell and Robert Staiger, eds., Handbook of Commercial Policy; Amsterdam: North Hollland.

[37] Gopinath, Gita (2015), "The international price system" NBER WP 21646.

[38] Gopinath, Gita, and O. Itskhoki (2010), "Frequency of Price Adjustment and Pass-Through" Quarterly Journal of Economics 125, 675-727.

[39] Kee, Hiau Looi, A. Nicita, and M. Olarreaga (2009), "Estimating Trade Restrictiveness Indices"; Economic Journal 119, 172-199.

[40] Kim, Euysung. (2000), "Trade Liberalization and Productivity Growth in Korean Manufacturing Industries: Price Protection, Market Power, and Scale Efficiency"; Journal of Development Economics 62, 55-83. 
[41] Kimball, M.S. (1995) "The quantitative analytics of the basic neomonetarist model"; Journal of Money, Credit and Banking 27, 1241-1277.

[42] Konings, Jozef, and H. Vandenbussche (2005), "Antidumping Protection and Markups of Domestic Firms"; Journal of International Economics 65, 151-65.

[43] Krugman, Paul (1986), "Pricing-to-market when the Exchange Rate Changes"; NBER working paper 1926; Cambridge, MA: National Bureau of Economic Research.

[44] Leamer, Edward (1990), "The Structure and Effects of Tariffs and Nontariff Barriers in 1983", in Ronald W. Jones and Anne O. Krueger (eds.), The Political Economy of International Trade; Cambridge, MA: Basil Blackwell.

[45] Li, Hongbin, H. Ma, and Y. Xu (2015), "How do exchange rate movements affect Chinese exports? A firm-level investigation", Journal of International Economics 97, 148-161.

[46] Mallick, Sushanta, and H. Marques (2010) "Data Frequency and Exchange Rate PassThrough: Evidence from India's Exports". International Review of Economics 8 Finance $19,13-22$.

[47] Mayer, Thierry, and G. Ottaviano (2007), "The happy few: the internationalisation of European firms' '; Intereconomics 43, 135-148.

[48] Melitz, Marc, and G. Ottaviano (2008), "Market Size, Trade, and Productivity"; Review of Economic Studies 75, 295-316.

[49] Nieberding, James F. (1999), "The Effect of US Antidumping Law on Firms' Market Power: An Empirical Test"; Review of Industrial Organization 14, 65-84.

[50] Pierce, Justin R. (2011), "Plant-Level Responses to Antidumping Duties: Evidence from U.S. Manufacturers"; Journal of International Economics 85, 222-233.

[51] Rollo, Valentina (2014), "Unexpected pricing to market in goods classified as homogeneous", CTEI Working Paper.

[52] Rovegno, Laura (2013), "Trade protection and market power: evidence from US antidumping and countervailing duties"; Review of World Economics 149, 443-476. 